IZA DP No. 10370

Management Practices and Productivity in Germany

Sandra Broszeit

Ursula Fritsch

Holger Görg

Marie-Christine Laible

November 2016 


\title{
Management Practices and Productivity in Germany
}

\author{
Sandra Broszeit \\ Institute for Employment Research \\ Ursula Fritsch \\ Kiel Institute for the World Economy \\ Holger Görg \\ Kiel Institute for the World Economy \\ and IZA \\ Marie-Christine Laible \\ Institute for Employment Research
}

\section{Discussion Paper No. 10370 \\ November 2016}

\author{
IZA \\ P.O. Box 7240 \\ 53072 Bonn \\ Germany \\ Phone: +49-228-3894-0 \\ Fax: +49-228-3894-180 \\ E-mail: iza@iza.org
}

\begin{abstract}
Any opinions expressed here are those of the author(s) and not those of IZA. Research published in this series may include views on policy, but the institute itself takes no institutional policy positions. The IZA research network is committed to the IZA Guiding Principles of Research Integrity.

The Institute for the Study of Labor (IZA) in Bonn is a local and virtual international research center and a place of communication between science, politics and business. IZA is an independent nonprofit organization supported by Deutsche Post Foundation. The center is associated with the University of Bonn and offers a stimulating research environment through its international network, workshops and conferences, data service, project support, research visits and doctoral program. IZA engages in (i) original and internationally competitive research in all fields of labor economics, (ii) development of policy concepts, and (iii) dissemination of research results and concepts to the interested public.
\end{abstract}

IZA Discussion Papers often represent preliminary work and are circulated to encourage discussion. Citation of such a paper should account for its provisional character. A revised version may be available directly from the author. 
IZA Discussion Paper No. 10370

November 2016

\section{ABSTRACT}

\section{Management Practices and Productivity in Germany*}

Based on a novel dataset, the "German Management and Organizational Practices" (GMOP) Survey, we calculate establishment specific management scores following Bloom and van Reenen as indicators of management quality. We find substantial heterogeneity in management practices across establishments in Germany, with small firms having lower scores than large firms on average. We show a robust positive and economically important association between the management score and establishment level productivity in Germany. This association increases with firm size. Comparison to a similar survey in the US indicates that the average management score is lower in Germany than in the US. Overall, our results point towards lower management quality being at least in part to blame for the differences in aggregate productivity between Germany and the US.

JEL Classification: D24, L2, M2

Keywords: management practices, firm performance, labor productivity, GMOP, MOPS

Corresponding author:

Holger Görg

Kiel Institute for the World Economy

Kiellinie 66

24105 Kiel

Germany

E-mail: holger.goerg@ifw-kiel.de

\footnotetext{
* The authors would like to thank Nick Bloom, John van Reenen, Lutz Bellmann, Jörg Heining, Dana Müller, Till von Wachter, Stefanie Wolter, the participants of the Workshop on Management and Firm Performance in Kiel 2015, the Aarhus Kiel Workshop 2015 and the PHD Workshop in Braga 2016 for helpful comments and suggestions. The GMOP Survey was conducted jointly with the Institute for Applied Social Sciences (infas). Financial support from the Leibniz Association is gratefully acknowledged.
} 


\section{Introduction}

The recent economics literature has pointed out the existence of substantial differences in productivity levels, even amongst similarly developed countries such as the US and Germany. The OECD (2015) for example shows that aggregated labor productivity growth (measured in GDP per hour worked) in Germany has lagged substantially behind the US for the last two decades. These differences are surprising as they persist when controlling for factor inputs, exporting and importing, research and development activates (R\&D) and innovation, variation in output prices etc. (Roeger, Varga, and in 't Veld, 2010). Thus, when taking into account these productivity-determining factors, large productivity differences remain even in narrowly defined industries (Syverson, 2011). Being a good indicator of countries' competitiveness and industry location attractiveness, pinpointing the determinants of productivity has become increasingly interesting to economists and policy makers.

In this context, intrafirm behavior has long been recognized as a potentially important driver of productivity (Mundlak, 1961; Leibenstein, 1966). Due to a lack of data and a missing concept to measure management quality, it has not been part of mainstream empirical work for a long time however. First evidence that management practices and organizational behavior positively impact firm performance was provided by management schools (e.g., Lin and Shih, 2008; Datta, Guthrie, and Wright, 2005; Huselid, 1995). While valuable in itself, case study evidence cannot resolve the existing deficit in understanding the role of management practices for shaping a firm's productivity, especially when firms are regarded in the aggregate or at the country level.

Against this backdrop, since the beginning of the 21st century an innovative and growing strand of economic research has been focusing on the role of management practices in terms of monitoring, incentivizing and promoting workers in order to explain productivity differences (Bloom and van Reenen, 2007; Bloom and van Reenen, 2010). Using data from the World Management Survey (WMS) ${ }^{1}$, a survey with open ended questions conducted in several countries all over the world, Bloom and van Reenen $(2007,2010)$ provide evidence for a positive link between management and performance. However, these surveys only include a small number of firms per country, e.g., around 700 for the US and around 300 for Germany. Hence, systematic and comprehensive measurements of management practices and assessments of the relationship between management and firm performance are still in their infancy and this deficit stems among others from the lack of large-scale data on management practices.

Based on the WMS questionnaire, in 2010 the US Census Bureau carried out the "Management and Organizational Practices Survey" (MOPS). The data include infor-

\footnotetext{
${ }^{1}$ See www.worldmanagementsurvey.com and Bloom et al. (2016).
} 
mation on over 30,000 manufacturing firms in the US and provide information on management practices and firm characteristics for the years 2005 and 2010. The survey is reported on in Bloom et al. (2013). ${ }^{2}$ Results from this data show that management practices have become more structured, in the sense of involving more data collection and analysis (e.g., for production targets or bonus payments). Furthermore, a strong positive correlation between the measured management quality and firm performance was observed (Bloom et al., 2013).

We built on this research and conducted a similar survey among establishments in Germany, the "German Management and Organizational Practices" (GMOP) Survey. ${ }^{3}$ The main structure of the survey is based on MOPS, which allows a direct comparison with the findings for the US. As in the US, the GMOP interviews were conducted in a large number of establishments and provide information on management practices and firm characteristics. We collected information on over 1,900 establishments across German manufacturing industries for the years 2008 and 2013. Compared to the WMS, MOPS and GMOP only include closed ended questions.

In this paper, we introduce the novel GMOP dataset and analyze the extent and dissemination of management practices in Germany. Adopting the methodology used by Bloom et al. (2013) to calculate an index of management quality that is comparable across establishments, we show that there is substantial heterogeneity in this score across establishments. This indicates widespread differences in management practices within Germany. We attempt to explain the observed heterogeneity in management quality by using observable firm characteristics relating to earlier work by Bloom and van Reenen $(2007,2010)$. Furthermore, we investigate the link between management and labor productivity and find that the management score is positively and robustly related to labor productivity. Given that the calculated management scores for Germany are, on average, lower than in the US, lower management quality may explain at least partly the productivity differences between the US and Germany that were alluded to above.

The rest of the paper is structured as follows: Section two presents the data and the construction of the management score, and provides evidence on the score's drivers. The relationship between management practices and establishment productivity is investigated in section three. The results of various extensions and robustness checks are shown in section four. Section five concludes the paper.

${ }^{2}$ For further information on MOPS and the survey questionnaire, see http://www.managementinamerica.com/.

${ }^{3}$ Besides Germany, Australia, Canada, Denmark, Japan, Mexico, Pakistan, and the UK also adopted the MOPS questionnaire for comparable surveys. 


\section{Management in Germany - Data and descriptive evidence}

\subsection{Introducing the survey}

The GMOP survey was carried out jointly by the Kiel Institute for the World Economy (IfW), the Institute for Employment Research (IAB) and the Institute for Applied Social Sciences (infas). ${ }^{4}$ As part of the survey, 1,927 establishments provided detailed information on management practices and establishment characteristics. The paper-and computer-based surveys were carried out in late 2014 and early 2015 providing information relating retrospectively to the years 2008 and 2013. The survey design and the questionnaire are deliberately closely related to the US MOPS. The survey starts with a block of questions on management practices related to monitoring, targets and incentives. These are the standard management questions used in earlier work by Bloom et al. (2013) and also in other studies based on the WMS (e.g., Bloom and van Reenen, 2007, 2010). The second part of the questionnaire pertains to background information on the establishments, like ownership and qualification structures. Additionally, performance indicators such as revenue, exports, and innovations are inquired about. The questionnaire also collects personal characteristics of the respondent, like tenure and position in the establishment, which will be used as controls in the econometric analyses.

The sample was drawn from German administrative establishment data (Gruhl, Schmucker, and Seth, 2012) merged with commercial data from Bureau van Dijk (BvD). ${ }^{5}$ To make the data comparable with the US data, we restrict the study population to establishments in the manufacturing industry. Further we only use establishments with 25 or more employees liable to social security. We drew a gross sample stratified by firm size, industry and settlement structure. In total, 1,927 establishments gave a valid interview which implies a response rate of 6 percent. The appendix A1 as well as Broszeit and Laible (2016) provide more details on the survey and a discussion of the representativeness of the sample. Overall, the data is quite representative and unit non-response is unlikely to affect the results. ${ }^{6}$

\subsection{How management can be measured - Constructing the man- agement score}

The questionnaire asks about 16 management practices, which can broadly be classified into two groups, (i) targets and incentives (I\&T) and (ii) data driven performance

\footnotetext{
${ }^{4}$ For basic information on the project, see www.gmop-survey.de.

${ }^{5}$ For this sample, firms from BvD were matched with establishments in the administrative data of the IAB (Establishment History Panel) through record linkage procedures under the assumption that the links were randomly matched (compare Antoni et al., 2016; Schild, 2016). Thus, the resulting sample should be a random selection of establishments. One establishment per firm was randomly chosen from this sample. The reason for drawing from linked IAB-BvD data was to later being able to merge the survey data to additional commercial information like operating revenue or capital, which is included in BvD at the firm level.

${ }^{6}$ Note that the data also provides sampling weights which are used to compute representative descriptive statistics.
} 
monitoring (DDPM). The term "targets" refers to the communication of production targets to managers and non-managers, the time frame of targets as well as to the degree of effort that is required to achieve production targets. "Incentives" measure the use of performance bonuses, promotions and the dealing with underperforming employees. "Data driven performance monitoring" refers to the recording and reviewing of key performance indicators, the use of production display boards and to problem solving in the production process.

The first step in the empirical analysis is to aggregate the available survey information. Adopting the methodology described in Bloom et al. (2013), we construct a synthetic management score. This score is a measure of how structured management is at the establishment level and may as such be interpreted as a measure of management "quality". Our methodology enables us to compare directly the German management score with the US one.

As do Bloom et al. (2013), we compile the answers from the 16 management questions into one measure reflecting structured management. We only use observations with at least 11 non-missing values in the 16 management items. Then the responses to each question are normalized on a 0 to 1 scale with the most structured management practice corresponding to 1 and the least to 0. According to Bloom et al. (2013) "structured" management practices are defined "as those that are more specific, formal, frequent or explicit" (Bloom et al., 2013, p.21). If questions have more than two categories, the middle categories are assigned shares. For example, in the question "How many key performance indicators were approximately monitored at this establishment?" the least structured answer is "1-2" and is assigned a 0 . The categories in between, i.e. "3-9" and "10-49", are assigned 0.25 and 0.75 respectively. The most structured category " 50 or more" is assigned a 1 . Finally, we calculate the management score as the unweighted average of the normalized responses. Thus the management score lies between 0 and 1, with 0 indicating that the establishment does not use structured practices and 1 that the establishment uses all measures. The underlying assumption is that more structured management practices employed by a firm imply better management and hence lead to a higher management indicator. To construct the index, each question's answer options are rated according to the aforementioned principles and ordered from best to worst answer option. Each management score thus reflects an establishment's choice of particular management practices.

Figure 1 shows the distribution of the management score across establishments in 2008 and 2013. It is evident that there is substantial heterogeneity in this measure across establishments. The mean value of the management score has risen from 0.50 (SD: 0.17 ) in 2008 to 0.57 (SD: 0.16 ) in 2013. This means that the average quality of management in German establishments, as measured by the management score, has increased substantially between 2008 and 2013. 
Figure 1: Distribution of the management score in 2008 and 2013

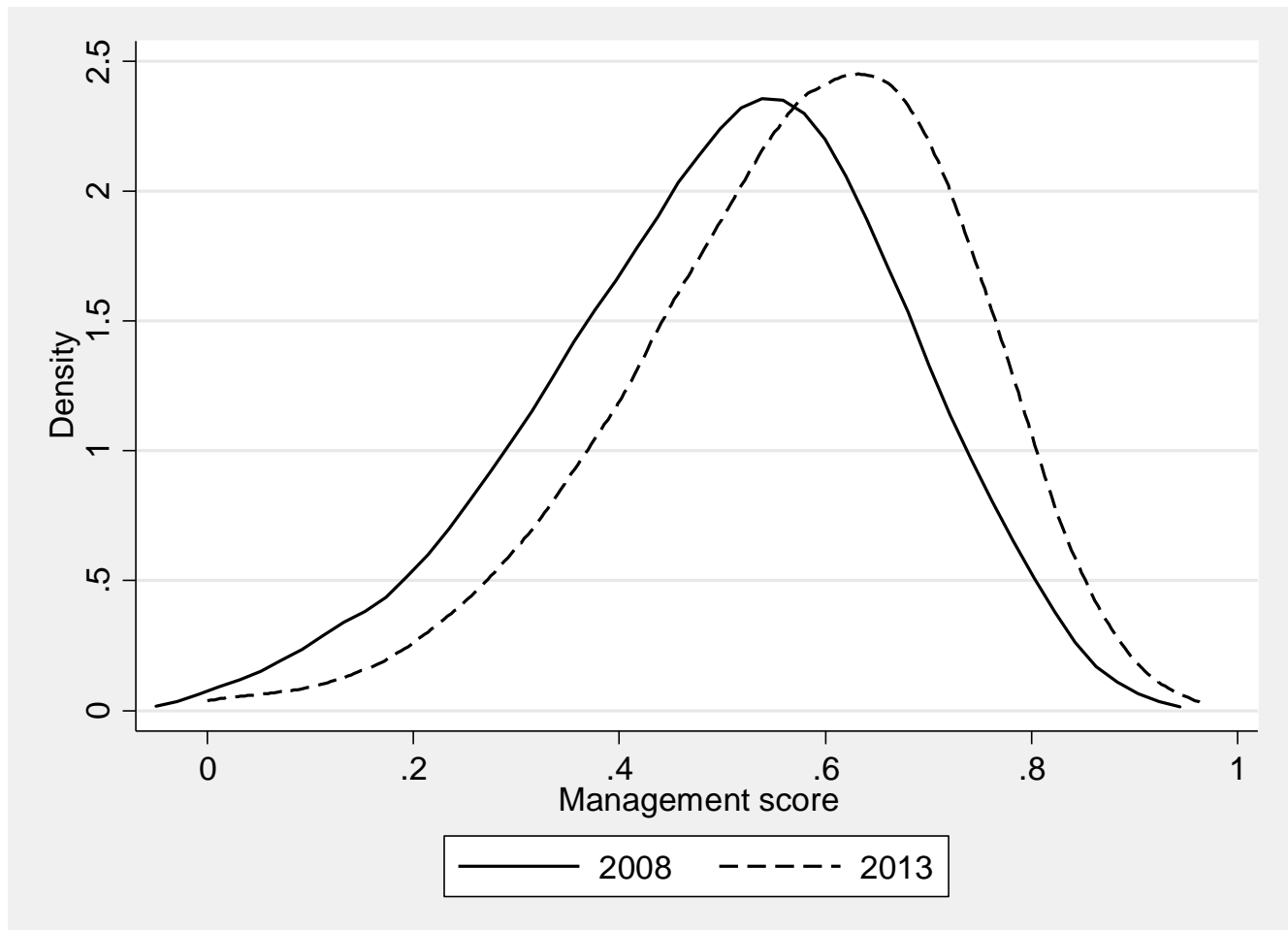

Notes: Weighted observations.

Source: Own calculations based on GMOP.

We can compare this result with the management scores estimated by Bloom et al. (2013) for the US. The average management scores for the US are 0.52 in 2005 and 0.59 in 2010 (see Figure A1 in the appendix A3). Hence, the measured management quality is higher in the US than in Germany, and this difference seems to be roughly constant over the two survey years. ${ }^{7}$ This is in line with Bloom and van Reenen (2007), who use the WMS data and find that US firms have on average better management than European firms (France, UK, Germany).

To look in more detail at the management index for Germany, we split up the management score into its two components, i.e. I\&T and DDPM. Figure 2 shows that the level of I\&T is above that of DDPM, however DDPM has experienced a higher growth between 2008 and 2013. This development suggests that the increase of the overall management score is driven primarily by DDPM.

\footnotetext{
${ }^{7}$ Notably, this difference remains in place even though the US survey lags three years behind the German survey (i.e. the years of comparison are 2005 and 2008; as well as 2010 and 2013). This means that even measured three years later, management practices are not as commonly used in Germany as in the US.
} 
Figure 2: Splitting up the indicator
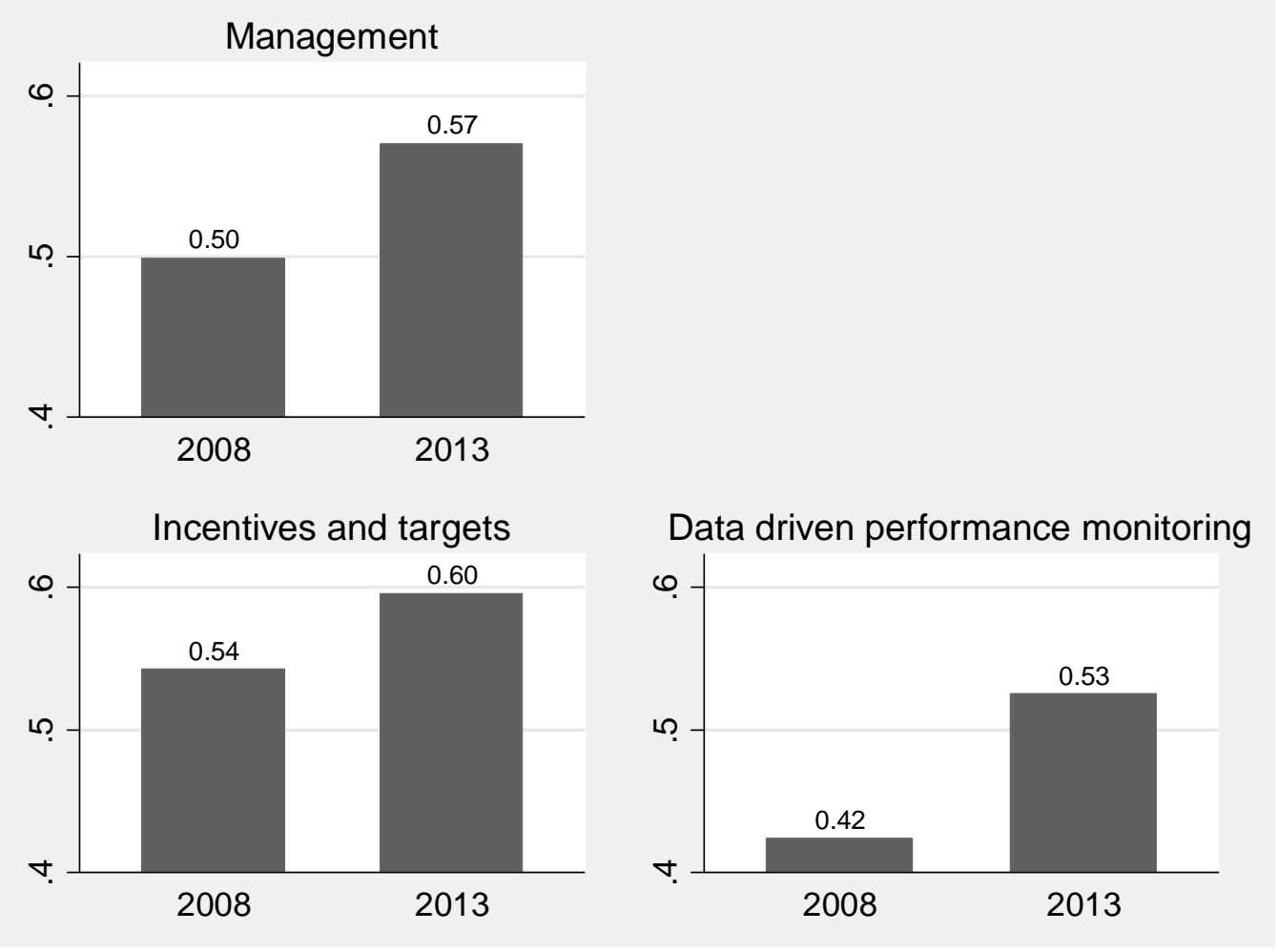

Notes: Weighted observations.

Source: Own calculations based on GMOP.

Another way to slice up our data is by looking at different firm sizes. Germany is well known for the importance of small and medium-sized enterprises (SMEs), the German Mittelstand, which are generally considered as the backbone of the German manufacturing sector (Federal Ministry of Economics and Technology, 2013). In order to relate to this discussion, we depict the variation in the management score across different firm size classes in 2013 (Figure 3). While the German definition of SMEs usually includes firms with up to 500 employees, the European definition sets the limit at a lower level of 250 employees (European Commission, 2016). In the graph, we thus define three groups: (i) small establishments with less than 50 employees, (ii) medium-sized establishments with 50 to 249 employees and (iii) large establishments with 250 or more employees. ${ }^{8}$

\footnotetext{
8 Note that our sample was drawn from administrative data in 2011 and restricted to establishments with at least 25 employees liable to social security. Since for the surveyed years 2008 and 2013 , some establishments indicated values below 25 , we name the first category "less than 50 employees" instead of "25-49 employees". The share of establishments with less than 25 employees in the surveyed years is around 6 percent, 1 percent has less than 10 employees. All conducted descriptive and multivariate analyses yield largely similar results with and without these smaller establishments. We thus decided to keep them in the sample and mark single deviations in footnotes.
} 
Figure 3: Management scores across firm size in 2013

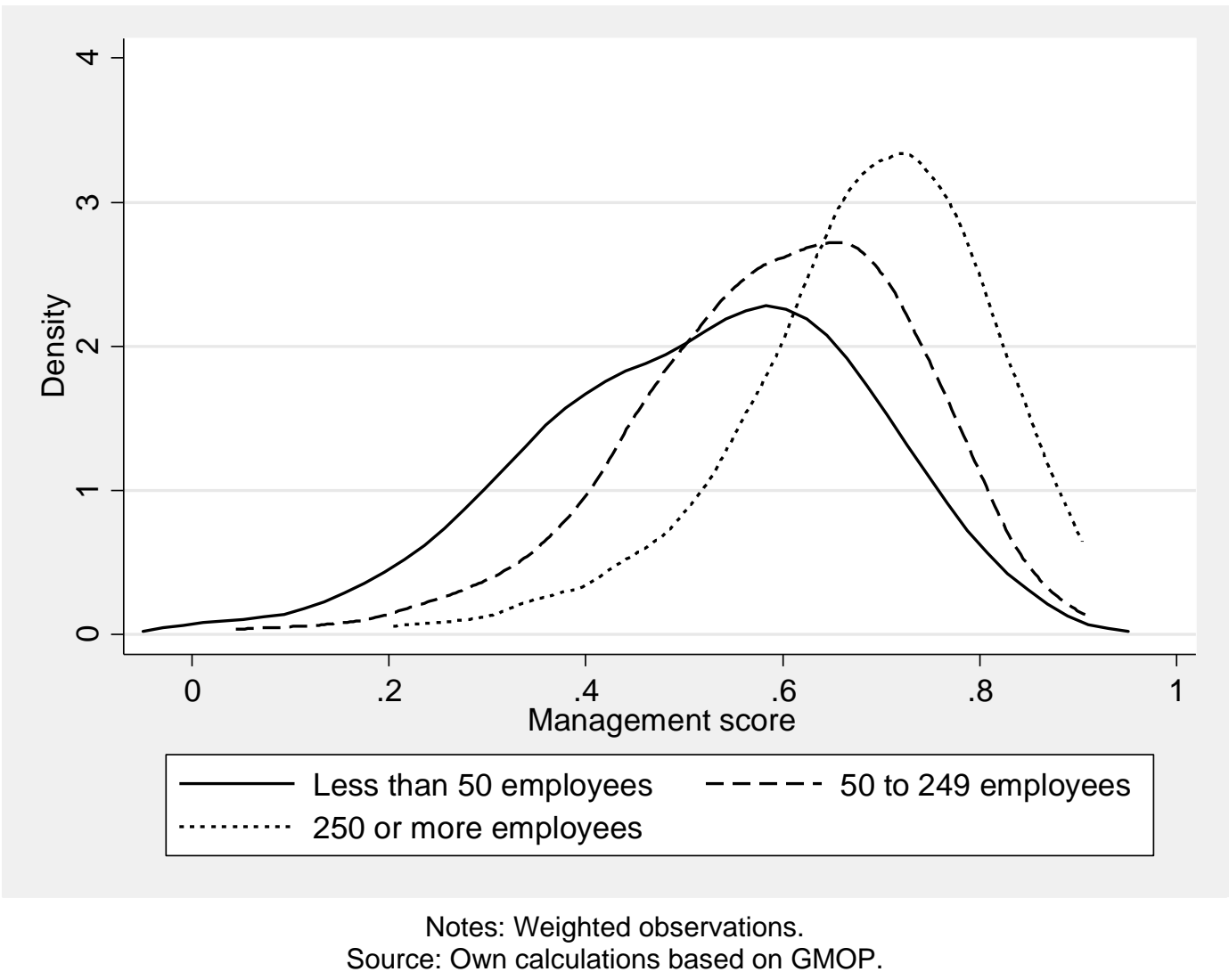

We see that the management score increases with firm size and that heterogeneity is a feature of all three size classes. In the left tail of the distributions we observe fewer establishments with low management scores in the largest size class compared to the other two. This is mirrored on the right side with more establishments showing high scores $(>0.8)$ in the largest size class. This pattern is reflected in the mean values, which are 0.52 (SD: 0.17$), 0.59$ (SD: 0.14) and 0.68 (SD: 0.12) respectively for the small, medium and large size categories. These observed differences are statistically significant. In other words: the larger the firm, the more structured and, in this sense, "better" is the management on average. Medium-sized establishments are thus doing better than small establishments, but on average lag behind large establishments in terms of their management structure. Bloom et al. (2013) present a similar finding for the US. As investments in management are to a large extent fixed costs, it is perhaps not surprising to see evidence for such increasing returns to scale in management.

Figure A2 in the appendix A3 combines Figures 2 and 3 and shows changes in I\&T and DDPM over the three firm size categories. As seen above, the overall increase in the management score is predominantly driven by the high increase in DDPM. This applies throughout all size categories and could reflect a common trend of technological upgrading. With an increase from 0.54 in 2008 to 0.69 in 2013, large establishments with 250 or more employees stand out even more. Like in the US (Brynjolfsson and McElheran, 2016), small firms seem to adopt DDPM later, but are well on their way. 


\subsection{What drives the management score?}

Having demonstrated that substantial heterogeneity exists in management scores across establishments, the question arises which establishments are most likely to implement structured management practices. Bloom and van Reenen $(2007,2010)$ discuss several possible drivers of the management score, either internal or external to the firm, which we in turn investigate for Germany.

First, certain firm characteristics can drive the management score. For example, Bloom and van Reenen (2010) argue that ownership matters, specifically whether a firm is family-owned or not. They hypothesize that family ownership could have two opposing effects on management. On the one hand, it may be positive as it potentially reduces the principal-agent problem inherent in firms with diversified ownership structures. On the other hand, family ownership may reduce the pool of available managers, if these are chosen from within the family. Their findings support these hypotheses in so far as family firms choosing managers from a large group of family members are no worse than others. However when the top management position is filled by the eldest son by default, firms' management quality is significantly worse.

Bloom and van Reenen (2010) further argue that foreign multinationals have better management practices, due to a selection effect as in Helpman, Melitz, and Yeaple (2004). Better managed firms are more able to overcome the sunk costs of investing abroad. Thus, multinationals have on average better management quality. ${ }^{9}$ Related to this selection mechanism is the implication that exporters have better management than non-exporters, but that the "management premium" for exporters is below that of multinationals. Bloom and van Reenen (2010) also show that a firm's skill intensity is positively correlated with management quality for two reasons. On the one hand, better skilled managers are able to implement more high-quality management practices. On the other hand, implementing high-quality management techniques is easier if the workforce is also skilled, thereby reinforcing the positive effects of management quality.

Second, factors relating to the firm's environment can also determine management quality. Bloom and van Reenen (2010) argue that fierce product market competition forces firms to employ the best management practices in order to survive. Accordingly, badly performing firms drop out of the market (van Reenen, 2011). Another explaining factor for management score differences are labor market regulations. Stringent regulation may prevent firms to implement the most efficient management techniques related to hiring, firing or promoting workers and therefore reduce the management score. As opposed to country- or sector-specific regulations, there are firm

\footnotetext{
${ }^{9}$ While Bloom and van Reenen (2010) only look at foreign multinationals, the GMOP data also includes a variable on whether an establishment has any affiliates abroad - i.e., we know whether a German establishment is a multinational. We experimented with this variable but did not find any statistically significant association with the management score.
} 
level differences in labor market regulations, in particular when it comes to the implementation of works councils. This labor market institution is particularly important in Germany.

Using the GMOP data, the management score is regressed on the variables discussed above. ${ }^{10} \mathrm{We}$ implement OLS estimations, as we want to provide first evidence on associations in the data, which may then be explored further in future research. Since there are two observations per establishment available, one for 2008 and 2013, we pool the data, include a year dummy for 2008 and cluster the standard errors by establishment. The results are reported in Table 1. First we look at each establishment level variable individually and then we estimate a full model with all variables included simultaneously.

The regressions show positive and statistically significant coefficients for size as measured by the natural logarithm of the sum of managers and non-managers. Further, there is a positive association between foreign ownership ( 1 if establishment is in foreign owned), skills of managers (categorical variables that gives the percentage of managers with university degree), and exporting ( 1 if establishment indicated to export). We do not find any significant correlation between family ownership ${ }^{11}$, skills of non-managers, presence of works councils or the level of competition ( 1 if the establishment reported to face very high levels of competitive pressure) and the management score. Note that when looking at each column individually we see that the size variable has the highest explanatory power as judged by the adjusted R-squared. Conditional on industry, year and settlement dummies ${ }^{12}$, variations in the size variable explain about 15 percent of the variation in management scores across establishments.

\footnotetext{
${ }^{10}$ For an overview of the variable definitions see Table A2 in the appendix A2.

${ }^{11}$ We cannot control for family management.

12 Industry dummies are food and consumption, consumer products, industrial goods, investment and durable goods and construction. Settlement dummies are larger cities, urban regions, and rural regions with signs of densification as well as sparsely populated rural regions.
} 
Table 1: Determinants of the management score

\begin{tabular}{|c|c|c|c|c|c|c|c|c|c|}
\hline $\begin{array}{l}\text { Dependent Variable: } \\
\text { Management Score }\end{array}$ & (1) & (2) & (3) & (4) & (5) & (6) & (7) & (8) & (9) \\
\hline Size (In) & $\begin{array}{l}0.047^{\star \star \star} \\
(0.004)\end{array}$ & & & & & & & $\begin{array}{l}0.043^{\star \star \star} \\
(0.004)\end{array}$ & $\begin{array}{l}{ }^{*} 0.044^{\star \star \star} \\
(0.004)\end{array}$ \\
\hline Foreign ownership (D) & & $\begin{array}{c}0.062^{\star \star \star} \\
(0.010)\end{array}$ & & & & & & $\begin{array}{l}0.032^{\star * \star} \\
(0.010)\end{array}$ & $\begin{array}{l}{ }^{*} 0.034^{\star \star *} \\
(0.010)\end{array}$ \\
\hline Family ownership (D) & & & $\begin{array}{l}-0.015^{\star} \\
(0.008)\end{array}$ & & & & & $\begin{array}{l}-0.007 \\
(0.008)\end{array}$ & $\begin{array}{l}-0.010 \\
(0.007)\end{array}$ \\
\hline $\begin{array}{l}\text { Managers: } \\
\text { university degree }\end{array}$ & & & & $\begin{array}{l}0.011^{\star * *} \\
(0.003)\end{array}$ & & & & $\begin{array}{l}0.009^{\star \star *} \\
(0.003)\end{array}$ & $\begin{array}{c}\star 0.009 * \star * \\
(0.003)\end{array}$ \\
\hline $\begin{array}{l}\text { Non-managers: uni- } \\
\text { versity degree }\end{array}$ & & & & $\begin{array}{l}0.011^{*} \\
(0.007)\end{array}$ & & & & $\begin{array}{c}0.002 \\
(0.006)\end{array}$ & $\begin{array}{l}0.004 \\
(0.006)\end{array}$ \\
\hline Works council (D) & & & & & $\begin{array}{l}0.043^{\star \star \star} \\
(0.008)\end{array}$ & & & $\begin{array}{l}-0.006 \\
(0.008)\end{array}$ & $\begin{array}{l}-0.008 \\
(0.008)\end{array}$ \\
\hline Exports (D) & & & & & & $\begin{array}{c}0.051^{\star \star \star} \\
(0.010)\end{array}$ & & $\begin{array}{l}0.024^{\star *} \\
(0.010)\end{array}$ & $\begin{array}{l}0.022^{\star *} \\
(0.010)\end{array}$ \\
\hline Competition (D) & & & & & & & $\begin{array}{l}0.006 \\
(0.007)\end{array}$ & $\begin{array}{c}0.001 \\
(0.007)\end{array}$ & $\begin{array}{l}-0.000 \\
(0.007)\end{array}$ \\
\hline Year & & & yes & yes & yes & yes & yes & ye & yes \\
\hline & yes & yes & yes & yes & yes & ye & ye & $y \in$ & yes \\
\hline nies & yes & yes & yes & yes & yes & yes & yes & yes & yes \\
\hline & no & no & no & no & no & no & no & no & yes \\
\hline Observations & 2,651 & 2,651 & 2,651 & 2,651 & 2,651 & 2,651 & 2,651 & 2,651 & 2,651 \\
\hline & 0.156 & 0.088 & 0.074 & 0.089 & 0.089 & 0.087 & 0.072 & 0.175 & 0.194 \\
\hline Adjusted R-squared & 0.154 & 0.085 & 0.071 & 0.085 & 0.086 & 0.084 & 0.069 & 0.170 & 0.188 \\
\hline
\end{tabular}

Notes: OLS estimations with pooled data. Clustered robust standard errors at the establishment level are in parentheses. Noise controls include gender, tenure and position of respondent as well as a dummy for answering online. $\mathrm{D}$ indicates a dummy variable. Asterisks indicate significance levels: * $\mathrm{p}<$ $0.10, * * p<0.05, * \star * p<0.01$.

Source: Own calculations based on GMOP.

\section{Management and labor productivity}

\subsection{Descriptive evidence}

We now turn to look at the association between the management score and labor productivity. If management is related to firm level productivity, then differences in management scores across countries may be able to explain productivity differences across countries as well, as argued by Bloom and van Reenen (2007).

The underlying assumption concerning this relationship is that management positively affects firm performance through several channels. First, the management practices that we inquire about in the survey show a certain level of structure in the firm, which make production and problem-solving processes more efficient and thereby increase productivity. Second, a higher level of employee supervision may lead to more pressure transferred to the employees, but also to a higher motivation level, employee effort and job satisfaction (Nagin et al., 2002). This in turn increases productivity as well (Böckerman and Ilmakunnas, 2012). Finally, there is a self-sorting process of workers, resulting from the fact that workers who are less productive leave the company or are not even hired (Lazear, 2000). This is in line with Bender et al. (2016), who find that better-managed firms have a higher share of workers and managers with above-average human capital than less-well managed firms. 
To obtain a first idea about the management-productivity relationship, Table 2 presents summary statistics for the baseline regression sample, depicting means and standard deviations for the main establishment level variables. We additionally group establishments into two groups based on their management indicator. Low management includes establishment observations with management scores below or at the median, high management above the median. In the last column indicates we indicate whether the differences are statistically different. The statistics show that establishments with high management scores are generally larger, have higher shares of managers with university degrees, are more likely to be foreign-owned, to be active abroad ( 1 if establishment took over a company abroad, set up a location or subsidiary abroad or had an equity participation amounting to a minimum of 10 percent of foreign companies), have a works council and to export. They also appear to be more productive judging by the mean of labor productivity.

Table 2: Sample summary statistics

\begin{tabular}{|c|c|c|c|c|c|c|c|}
\hline & \multicolumn{2}{|c|}{ Total } & \multicolumn{2}{|c|}{ Low Management } & \multicolumn{2}{|c|}{ High Management } & \multirow[t]{2}{*}{ Difference } \\
\hline & Mean & SD & Mean & SD & Mean & SD & \\
\hline Employees & 128.41 & 349.02 & 86.16 & 166.84 & 171.28 & 462.22 & *** \\
\hline Size (In) & 4.211 & 0.89 & 4.00 & 0.82 & 4.42 & 1.01 & $\star \star \star *$ \\
\hline \multicolumn{8}{|c|}{ Managers: university degree } \\
\hline$<=20 \%$ & 0.49 & 0.50 & 0.55 & 0.50 & 0.43 & 0.50 & *** \\
\hline $21-40 \%$ & 0.14 & 0.34 & 0.11 & 0.32 & 0.16 & 0.37 & *** \\
\hline $41-60 \%$ & 0.12 & 0.33 & 0.11 & 0.32 & 0.13 & 0.34 & \\
\hline $61-80 \%$ & 0.10 & 0.29 & 0.09 & 0.29 & 0.10 & 0.30 & \\
\hline$>80 \%$ & 0.15 & 0.36 & 0.13 & 0.34 & 0.17 & 0.38 & $* *$ \\
\hline Productivity (In) & 11.19 & 0.63 & 11.10 & 0.60 & 11.31 & 0.65 & $\star \star \star *$ \\
\hline Foreign Ownership (D) & 0.10 & 0.31 & 0.07 & 0.26 & 0.13 & 0.34 & *** \\
\hline Works council (D) & 0.38 & 0.49 & 0.34 & 0.47 & 0.41 & 0.49 & *** \\
\hline Engagement aboard (D) & 0.18 & 0.39 & 0.15 & 0.36 & 0.21 & 0.41 & *** \\
\hline Exports (D) & 0.63 & 0.48 & 0.57 & 0.50 & 0.70 & 0.46 & 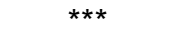 \\
\hline Management score & 0.55 & 0.15 & 0.43 & 0.11 & 0.68 & 0.07 & *** \\
\hline
\end{tabular}

Notes: Pooled data. Weighted observations. "Low management" includes establishment observations with management scores below or at the median, "high management" above the median. The last column indicates whether the differences are statistically different: ${ }^{*} p<0.10,{ }^{\star *} p<0.05$, ${ }^{\star \star *} p<0.01$. D indicates a dummy variable.

Source: Own calculations based on GMOP. 


\subsection{Baseline specification}

In order to investigate this link further we estimate productivity equations of the following form:

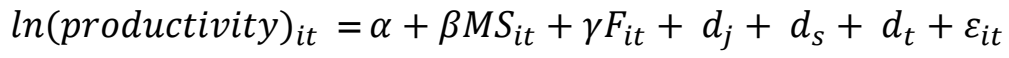

where the dependent variable is the natural logarithm of labor productivity, calculated as value added per worker. ${ }^{13}$ The subscript $i$ indexes the establishment and $t$ the survey year (2008 or 2013). MS is the management score and F is a vector of establishment level controls. The letters $d$ indicate vectors of dummies for industry, settlement type and survey year and $\varepsilon$ is the remaining error term. Standard errors are clustered by establishment. To reduce measurement error, the equation also includes a number of paradata and survey-specific variables as noise controls. These are dummies for the survey method (paper-and-pencil or online) and characteristics of the respondent (gender, tenure and position in the firm). In order to reduce the impact of outliers, we drop the bottom and top five percent of the productivity distribution. ${ }^{14}$

We start by estimating an OLS regression of productivity on the management score without controls. ${ }^{15}$ The coefficient reported in column 1 of Table 3 shows that there is a statistically significant and positive relationship between management quality and productivity at the establishment level. The point estimate of 0.69 implies that an increase in the management score by 0.1 points would be associated with an increase in productivity by 7.1 percent. ${ }^{16}$ Recall that the mean of the management score in Germany increased from 0.50 to 0.57 between 2008 and 2013. This change in management quality would be associated with an increase in labor productivity by 4.9

\footnotetext{
${ }^{13}$ Labor Productivity $=$ (Sales-Intermediates)/Employees. Note that in our survey we do not have information on the capital stock, which prevents us from calculating TFP.

${ }^{14}$ We drop the bottom and top five percent of the distribution, as we suspect measurement errors in the data due to two aspects. First, the respondent may not have answered the questions on sales, employees and inputs with reference to the establishment, but to the firm. Second, the item on sales in the survey may have been misleading as we inquired about sales in thousands. To refrain from using observations convoluted by measurement error, we drop them. Generating a dummy variable for outlier values and regressing it on all relevant variables revealed no systematic bias induced by the dropping. Table $A 1$ in the appendix provides evidence for the representativeness of the regression sample.

We also compared the GMOP productivity distribution to the productivity distribution in the IAB establishment panel, a yearly large-scale representative survey in over 15,000 German establishments. The comparison showed that there are strong outliers both in the bottom and top end of the distribution. Dropping the bottom and top five percent turned out to be necessary for the distributions to align.

${ }^{15}$ In order to investigate possible heterogeneity in the distribution of the dependent variable, we re-estimate Table 3 using quantile regression techniques. As the coefficients across the quantiles are not statistically significantly different from each other and do not vary extensively in size, we argue that using pooled OLS regressions is the reasonable choice.

${ }^{16} \exp (0.0689)=1.071$. Bloom et al. $(2013)$ calculate for the US that such an increase by 0.1 points in the management score is associated with an increase in labor productivity by 13.6 percent.
} 
percent over that period. ${ }^{17}$ To put it differently, a one standard-deviation change in the management quality would be associated with an increase in labor productivity by 11.3 percent. ${ }^{18}$ For the US, Bloom et al. (2013) calculate an increase by 21.3 percent, about twice the rate for Germany.

The result indicates that the US better leverages management practices compared to Germany. This observation may partly be due to a lower number of management practices used in Germany. Descriptive evidence shows that Germany and the US have similar overall scores for the component "incentives and targets", however Germany lags behind in terms of "data drive performance monitoring" (see Figure A1 in the appendix A3). One explanation for this finding could be that the average establishment size in Germany is smaller compared to the US ${ }^{19}$ and that smaller establishments may not see the need to implement structured monitoring practices. This hypothesis is in line with the results of Table 5 below which clearly indicate that the link between the management score and productivity increases with establishment size.

In the subsequent columns 2 to 5 of Table 3 we add more controls in order to make sure that the management score does not merely capture differences in size or other observable characteristics across establishments. ${ }^{20}$ While many of the characteristics are statistically significant as expected, they do not change the importance of management for labor productivity. While the magnitudes of the point estimates changes somewhat, they are all around 0.6. Column 6 shows the coefficients of a standard productivity function without including management. The estimation results are comparable with other production estimates in terms of size and significance. Bellmann and Hübler (2015) for example, who investigate the relationship between working time accounts and productivity, get similar coefficients for size and qualification structure.

${ }^{17} \exp \left(0.689^{*} 0.07\right)=1.049$, where 0.07 is the increase in the management score between 2008 and 2013.

${ }^{18} \exp (0.689 * 0.15)=1.113$, where 0.15 is the sample standard deviation of the German management score (see Table 2).

19 The average firm size in Bloom et al.'s (2013) analysis is 167 employees with a median of 80 . By contrast, the average number of employees in the analyses for Germany is 148 with a median of 70 .

${ }^{20}$ Since good management might be more pronounced in ambitious and leading-edge establishments, we additionally controlled for the implementation of product or process innovations, but did not observe any remarkable changes in the management score coefficient. 
Table 3: Management and labor productivity

\begin{tabular}{|c|c|c|c|c|c|c|}
\hline $\begin{array}{l}\text { Dependent Variable: } \\
\text { Labor Productivity }\end{array}$ & (1) & (2) & (3) & (4) & (5) & (6) \\
\hline Management score & $\begin{array}{l}0.689 * \star * \\
(0.109)\end{array}$ & $\begin{array}{c}0.631^{\star \star \star} \\
(0.112)\end{array}$ & $\begin{array}{l}0.604^{\star * *} \\
(0.119)\end{array}$ & $\begin{array}{l}0.591^{\star \star \star} \\
(0.117)\end{array}$ & $\begin{array}{l}0.605^{\star \star \star} \\
(0.120)\end{array}$ & \\
\hline Size (In) & & $\begin{array}{c}0.031 \\
(0.027)\end{array}$ & $\begin{array}{c}0.015 \\
(0.027)\end{array}$ & $\begin{array}{c}-0.088^{\star \star \star *} \\
(0.034)\end{array}$ & $\begin{array}{c}-0.088^{\star \star \star} \\
(0.032)\end{array}$ & $\begin{array}{l}-0.062^{\star} \\
(0.032)\end{array}$ \\
\hline \multicolumn{7}{|c|}{ University degree (ref: <=20\%) } \\
\hline $21-40 \%$ & & & $\begin{array}{l}0.114^{\star \star} \\
(0.053)\end{array}$ & $\begin{array}{c}0.070 \\
(0.051)\end{array}$ & $\begin{array}{c}0.064 \\
(0.051)\end{array}$ & $\begin{array}{c}0.080 \\
(0.051)\end{array}$ \\
\hline $41-60 \%$ & & & $\begin{array}{l}0.220^{\star \star *} \\
(0.055)\end{array}$ & $\begin{array}{l}0.173^{\star \star \star} \\
(0.052)\end{array}$ & $\begin{array}{l}0.167^{\star * \star} \\
(0.053)\end{array}$ & $\begin{array}{l}0.189^{* * *} \\
(0.052)\end{array}$ \\
\hline $61-80 \%$ & & & $\begin{array}{l}0.194^{\star * *} \\
(0.068)\end{array}$ & $\begin{array}{l}0.143^{* *} \\
(0.065)\end{array}$ & $\begin{array}{l}0.145^{* *} \\
(0.065)\end{array}$ & $\begin{array}{l}0.162^{\star *} \\
(0.066)\end{array}$ \\
\hline$>80 \%$ & & & $\begin{array}{l}0.194^{\star * *} \\
(0.054)\end{array}$ & $\begin{array}{l}0.114^{\star *} \\
(0.053)\end{array}$ & $\begin{array}{l}0.113^{* *} \\
(0.053)\end{array}$ & $\begin{array}{l}0.133^{\star *} \\
(0.054)\end{array}$ \\
\hline Foreign ownership (D) & & & & $\begin{array}{l}0.195^{\star \star \star} \\
(0.062)\end{array}$ & $\begin{array}{l}0.182^{\star \star \star} \\
(0.063)\end{array}$ & $\begin{array}{l}0.204^{\star \star \star} \\
(0.063)\end{array}$ \\
\hline Works council (D) & & & & $\begin{array}{l}0.262^{\star \star \star} \\
(0.047)\end{array}$ & $\begin{array}{l}0.259 * \star \star \\
(0.048)\end{array}$ & $\begin{array}{l}0.248^{\star \star \star} \\
(0.048)\end{array}$ \\
\hline Engagement abroad (D) & & & & $\begin{array}{c}0.241^{* * *} \\
(0.049)\end{array}$ & $\begin{array}{l}0.228^{\star *} \\
(0.049)\end{array}$ & $\begin{array}{c}0.229^{* \star *} \\
(0.050)\end{array}$ \\
\hline Exports (D) & & & & $\begin{array}{l}0.146^{\star \star \star} \\
(0.046)\end{array}$ & $\begin{array}{l}0.151^{\star \star \star} \\
(0.047)\end{array}$ & $\begin{array}{l}0.159^{\star * \star *} \\
(0.048)\end{array}$ \\
\hline Year dummy & no & no & yes & yes & yes & yes \\
\hline Industry dummies & no & no & yes & yes & yes & yes \\
\hline Settlement dummies & no & no & yes & yes & yes & yes \\
\hline Noise controls & no & no & no & no & yes & yes \\
\hline Observations & 1,772 & 1,772 & 1,772 & 1,772 & 1,772 & 1,772 \\
\hline R-squared & 0.029 & 0.031 & 0.065 & 0.144 & 0.152 & 0.134 \\
\hline Adjusted R-squared & 0.028 & 0.030 & 0.058 & 0.135 & 0.140 & 0.122 \\
\hline
\end{tabular}

Notes: OLS estimations with pooled data. Clustered robust standard errors at the establishment level are in parentheses. Noise controls include gender, tenure and position of respondent as well as a dummy for answering online. $D$ indicates a dummy variable. Asterisks indicate significance levels: * $p<$ $0.10,{ }^{* *} p<0.05,{ }^{* * *} p<0.01$. Sample standard deviations are provided in Table 2.

Source: Own calculations based on GMOP.

\subsection{Slicing up the indicator}

The management index is based on 16 questions relating to two broad aspects of management, i.e. incentives and targets (I\&T) and data driven performance management (DDPM). Figure 2 showed differences in the level and growth of these two components. In a next step we therefore aim to explore their separate impact on productivity. In order to do so, we break up the management score into its two components and use these as covariates in the productivity regression.

The results for the split management score, which are reported in Table 4, clearly show that both I\&T and DDPM are positively correlated with labor productivity. The coefficients reported in column 1, where both management indicators are included, are similar in size and significance. This finding indicates that both parts contribute separately to labor productivity and that the management score captures the overall effect adequately. 
Table 4: Management and productivity: Slicing up the indicator

\begin{tabular}{|c|c|c|c|c|c|c|c|}
\hline \multirow{2}{*}{$\begin{array}{l}\text { Dependent Variable: } \\
\text { Labor Productivity }\end{array}$} & \multicolumn{3}{|c|}{ I\&T and DDPM } & \multicolumn{4}{|c|}{ Incentives, Targets and Monitoring } \\
\hline & (1) & $(2)$ & (3) & (4) & (5) & (6) & (7) \\
\hline I\&T & $\begin{array}{c}0.298^{\star \star \star} \\
(0.108)\end{array}$ & $\begin{array}{l}0.417^{\star \star \star} \\
(0.099)\end{array}$ & & & & & \\
\hline DDPM & $\begin{array}{c}0.316^{\star \star *} \\
(0.113)\end{array}$ & & $\begin{array}{c}0.432^{\star \star *} \\
(0.103)\end{array}$ & & & & \\
\hline Incentives & & & & $\begin{array}{l}0.278^{\star \star \star} \\
(0.093)\end{array}$ & $\begin{array}{c}0.354^{\star \star *} \\
(0.090)\end{array}$ & & \\
\hline Targets & & & & $\begin{array}{c}0.013 \\
(0.070)\end{array}$ & & $\begin{array}{l}0.130^{\star *} \\
(0.065)\end{array}$ & \\
\hline Monitoring & & & & $\begin{array}{c}0.344^{\star * *} \\
(0.121)\end{array}$ & & & $\begin{array}{c}0.426^{\star \star \star} \\
(0.108)\end{array}$ \\
\hline Size (In) & $\begin{array}{l}-0.090^{\star \star \star} \\
(0.032)\end{array}$ & $\begin{array}{c}-0.078^{\star \star} \\
(0.032)\end{array}$ & $\begin{array}{c}-0.085^{\star \star \star} \\
(0.032)\end{array}$ & $\begin{array}{c}-0.095^{\star \star \star} \\
(0.033)\end{array}$ & $\begin{array}{l}-0.077^{\star \star} \\
(0.032)\end{array}$ & $\begin{array}{c}-0.063^{\star \star} \\
(0.032)\end{array}$ & $\begin{array}{c}-0.088^{\star \star \star} \\
(0.033)\end{array}$ \\
\hline \multicolumn{8}{|l|}{$\begin{array}{l}\text { University degree } \\
\text { (ref: <=20\%) }\end{array}$} \\
\hline $21-40 \%$ & $\begin{array}{c}0.062 \\
(0.051)\end{array}$ & $\begin{array}{c}0.071 \\
(0.050)\end{array}$ & $\begin{array}{c}0.065 \\
(0.051)\end{array}$ & $\begin{array}{c}0.065 \\
(0.051)\end{array}$ & $\begin{array}{c}0.075 \\
(0.050)\end{array}$ & $\begin{array}{c}0.078 \\
(0.051)\end{array}$ & $\begin{array}{c}0.067 \\
(0.051)\end{array}$ \\
\hline $41-60 \%$ & $\begin{array}{c}0.165^{\star \star \star} \\
(0.053)\end{array}$ & $\begin{array}{c}0.175^{\star \star \star} \\
(0.052)\end{array}$ & $\begin{array}{c}0.170 * \star * \\
(0.053)\end{array}$ & $\begin{array}{l}0.160 * \star \star \\
(0.053)\end{array}$ & $\begin{array}{c}0.176^{\star \star *} \\
(0.052)\end{array}$ & $\begin{array}{l}0.188^{\star * \star} \\
(0.052)\end{array}$ & $\begin{array}{c}0.167^{\star * \star} \\
(0.053)\end{array}$ \\
\hline $61-80 \%$ & $\begin{array}{l}0.146^{\star \star} \\
(0.065)\end{array}$ & $\begin{array}{l}0.147^{\star *} \\
(0.065)\end{array}$ & $\begin{array}{l}0.154^{\star *} \\
(0.065)\end{array}$ & $\begin{array}{l}0.146^{\star *} \\
(0.065)\end{array}$ & $\begin{array}{l}0.149^{\star \star} \\
(0.066)\end{array}$ & $\begin{array}{l}0.159^{\star \star} \\
(0.065)\end{array}$ & $\begin{array}{l}0.156^{\star \star} \\
(0.066)\end{array}$ \\
\hline$>80 \%$ & $\begin{array}{l}0.116^{\star *} \\
(0.053)\end{array}$ & $\begin{array}{l}0.116^{\star *} \\
(0.053)\end{array}$ & $\begin{array}{l}0.126^{\star *} \\
(0.053)\end{array}$ & $\begin{array}{l}0.114^{\star \star} \\
(0.053)\end{array}$ & $\begin{array}{l}0.115^{\star \star} \\
(0.054)\end{array}$ & $\begin{array}{l}0.123^{\star \star} \\
(0.054)\end{array}$ & $\begin{array}{l}0.125^{\star \star} \\
(0.053)\end{array}$ \\
\hline Foreign Ownership (D) & $\begin{array}{l}0.181^{* * *} \\
(0.063)\end{array}$ & $\begin{array}{l}0.191^{* * *} \\
(0.063)\end{array}$ & $\begin{array}{c}0.185^{\star \star *} \\
(0.063)\end{array}$ & $\begin{array}{l}0.179 * * * \\
(0.064)\end{array}$ & $\begin{array}{l}0.188^{* * *} \\
(0.064)\end{array}$ & $\begin{array}{l}0.194^{\star * *} \\
(0.064)\end{array}$ & $\begin{array}{c}0.185^{\star * \star} \\
(0.064)\end{array}$ \\
\hline Works council (D) & $\begin{array}{c}0.255^{\star \star \star} \\
(0.048)\end{array}$ & $\begin{array}{l}0.263^{\star * *} \\
(0.048)\end{array}$ & $\begin{array}{l}0.243^{\star * *} \\
(0.048)\end{array}$ & $\begin{array}{l}0.254^{\star * *} \\
(0.048)\end{array}$ & $\begin{array}{l}0.264^{\star \star *} \\
(0.048)\end{array}$ & $\begin{array}{l}0.249 * \star \star \\
(0.048)\end{array}$ & $\begin{array}{c}0.241^{\star \star *} \\
(0.047)\end{array}$ \\
\hline Engagement abroad (D) & $\begin{array}{c}0.230 \star \star \star \\
(0.049)\end{array}$ & $\begin{array}{c}0.225^{\star \star \star} \\
(0.049)\end{array}$ & $\begin{array}{c}0.234^{\star \star *} \\
(0.049)\end{array}$ & $\begin{array}{l}0.229 * \star \star \\
(0.049)\end{array}$ & $\begin{array}{l}0.223^{\star \star \star} \\
(0.050)\end{array}$ & $\begin{array}{l}0.229^{\star \star *} \\
(0.050)\end{array}$ & $\begin{array}{c}0.233^{\star \star \star *} \\
(0.050)\end{array}$ \\
\hline Exports (D) & $\begin{array}{l}0.152^{\star \star \star} \\
(0.047)\end{array}$ & $\begin{array}{l}0.151^{\star * *} \\
(0.048)\end{array}$ & $\begin{array}{c}0.158^{\star \star \star} \\
(0.048)\end{array}$ & $\begin{array}{l}0.153^{\star \star *} \\
(0.047)\end{array}$ & $\begin{array}{l}0.153^{\star \star *} \\
(0.048)\end{array}$ & $\begin{array}{c}0.159^{\star * *} \\
(0.048)\end{array}$ & $\begin{array}{c}0.159^{\star * *} \\
(0.047)\end{array}$ \\
\hline Observations & 1,772 & 1,772 & 1,772 & 1,763 & 1,763 & 1,763 & 1,763 \\
\hline & 0.152 & 0.146 & 0.147 & 0.153 & & & 0.146 \\
\hline Adjusted R-squared & 0.140 & 0.135 & 0.135 & 0.140 & 0.133 & 0.125 & 0.135 \\
\hline
\end{tabular}

Notes: OLS estimations with pooled data. Clustered robust standard errors at the establishment level are in parentheses. Year dummy, industry dummies, settlement dummies and noise control included. Noise controls include gender, tenure and position of respondent as well as a dummy for answering online. D indicates a dummy variable. Asterisks indicate significance levels: ${ }^{\star} p<0.10, * \star p<0.05$, *** $p<0.01$. Sample standard deviations are provided in Table 2.

Source: Own calculations based on GMOP.

Taking one more step, we can further split up the indicator into three instead of two components, namely incentives, targets and monitoring. Again we see that each component of the management score contributes separately to labor productivity. ${ }^{21}$ Experimental evidence documents a positive effect of performance pay incentives on employee productivity (Lazaer, 2000; Bandiera, Brankay, and Rasul, 2005), as well as a worker selection effect whereby employees with higher productivity sort into firms

\footnotetext{
${ }^{21}$ When we drop establishments with less than 25 employees, the coefficient for targets becomes insignificant.
} 
which offer relevant incentives (Shaw, 2009). Furthermore there is evidence that selection also occurs at the manager-level in so far as managers allocate productive employees to incentivized tasks (Burgess et al., 2010) or predominantly support and select the most productive workers when their own incentives are based on worker performance (Bandiera, Barankay, and Rasul, 2007). Our results corroborate the generally positive effect of incentives on firm productivity in a larger sample of firms. However, when including all three categories together in one regression, the coefficient for targets becomes statistically insignificant. This implies that the coefficient of targets might capture the beneficial effects of other management measures if included alone in the regression.

\subsection{Differences in firm size}

The descriptive analyses indicate that there is substantial heterogeneity in management scores across size classes (compare Figure 3 ). This raises the question as to whether management and productivity have the same relationship in small compared to large establishments. One could argue that even if small establishments were able to implement more structured management practices, they may not be able to reap the benefits from them, because they do not have the capacity in terms of for example workforce, skills, or capital to really make a difference. In order to look at this issue we divide the sample into three size categories as before: small $(<50)$, medium (50 to 249) and large establishments (>= 250 employees).

The results reported in Table 5 indicate that the correlation between productivity and the management score is by far the highest for large establishments, followed by medium-sized establishments. In fact, we only find a small and weakly significant correlation between management and productivity for small establishments. ${ }^{22}$ This suggests that improvements in management structure in small establishments do not lead to large improvements in productivity, which may be due to some internal constraints that prevent management to reap the benefits of management practices. Furthermore, it may also be that small establishments either do not need elaborate management practices due to the small number of employees to be managed or that the implementation and use of management practices relates to large (bureaucratic) costs that may offset the benefits.

\footnotetext{
${ }^{22}$ When we drop establishments with less than 25 employees, this coefficient becomes insignificant.
} 
Table 5: Management and productivity by firm size

\begin{tabular}{|c|c|c|c|}
\hline \multirow{2}{*}{$\begin{array}{l}\text { Dependent Variable: } \\
\text { Labor Productivity }\end{array}$} & \multicolumn{3}{|c|}{ Establishment Size } \\
\hline & $<50$ & $50-249$ & $>250$ \\
\hline Management score & $\begin{array}{l}0.386^{*} \\
(0.202)\end{array}$ & $\begin{array}{l}0.529 * \star * \\
(0.137)\end{array}$ & $\begin{array}{c}1.190^{\star \star \star \star} \\
(0.429)\end{array}$ \\
\hline Size (ln) & $\begin{array}{l}-0.664^{\star * \star} \\
(0.085)\end{array}$ & $\begin{array}{c}0.025 \\
(0.056)\end{array}$ & $\begin{array}{c}0.072 \\
(0.092)\end{array}$ \\
\hline \multicolumn{4}{|c|}{ University degree (ref: <=20\%) } \\
\hline $21-40 \%$ & $\begin{array}{c}0.118 \\
(0.096)\end{array}$ & $\begin{array}{c}0.009 \\
(0.059)\end{array}$ & $\begin{array}{c}0.079 \\
(0.158)\end{array}$ \\
\hline $41-60 \%$ & $\begin{array}{l}0.226^{\star \star} \\
(0.099)\end{array}$ & $\begin{array}{l}0.141^{\star \star} \\
(0.063)\end{array}$ & $\begin{array}{l}0.221 \\
(0.139)\end{array}$ \\
\hline $61-80 \%$ & $\begin{array}{l}0.237^{*} \\
(0.130)\end{array}$ & $\begin{array}{c}0.097 \\
(0.065)\end{array}$ & $\begin{array}{l}0.077 \\
(0.226)\end{array}$ \\
\hline$>80 \%$ & $\begin{array}{c}0.042 \\
(0.096)\end{array}$ & $\begin{array}{l}0.118^{\star *} \\
(0.060)\end{array}$ & $\begin{array}{l}0.055 \\
(0.157)\end{array}$ \\
\hline Foreign Ownership (D) & $\begin{array}{c}0.214 \\
(0.143)\end{array}$ & $\begin{array}{l}0.240^{\star * *} \\
(0.076)\end{array}$ & $\begin{array}{l}-0.203 \\
(0.140)\end{array}$ \\
\hline Works council (D) & $\begin{array}{l}0.350 * * * \\
(0.087)\end{array}$ & $\begin{array}{l}0.128 * * \\
(0.052)\end{array}$ & $\begin{array}{l}0.153 \\
(0.137)\end{array}$ \\
\hline Engagement abroad (D) & $\begin{array}{l}0.592^{\star \star *} \\
(0.142)\end{array}$ & $\begin{array}{l}0.115^{\star \star} \\
(0.050)\end{array}$ & $\begin{array}{l}0.004 \\
(0.112)\end{array}$ \\
\hline Exports (D) & $\begin{array}{l}0.174^{* *} \\
(0.070)\end{array}$ & $\begin{array}{l}0.134^{\star} \\
(0.073)\end{array}$ & $\begin{array}{l}0.035 \\
(0.189)\end{array}$ \\
\hline Observations & 618 & 960 & 194 \\
\hline R-squared & 0.341 & 0.172 & 0.225 \\
\hline Adjusted R-squared & 0.314 & 0.151 & 0.115 \\
\hline
\end{tabular}

Notes: OLS estimations with pooled data. Clustered robust standard errors at the establishment level are in parentheses. Year dummy, industry dummies, settlement dummies and noise control included. Noise controls include gender, tenure and position of respondent as well as a dummy for answering online. $\mathrm{D}$ indicates a dummy variable. Asterisks indicate significance levels: ${ }^{*} p<0.10,{ }^{\star \star} p<0.05$, ${ }^{* \star *}$ $p<0.01$. Sample standard deviations are provided upon request.

Source: Own calculations based on GMOP.

\subsection{Further sample splits}

While firm size is one aspect describing the German Mittelstand, the notion of small and medium-sized firms in Germany is also related to ownership. As the Federal Ministry of Economics and Technology (2013) points out, Mittelstand firms are often firms that are in family ownership. Recall from Table 1 that family ownership is not directly correlated with the management score, once other covariates are controlled for. However, there may still be implications for the relationship between management and productivity. For example, family-owned firms may be less efficient in reaping the benefits from new management techniques due to more traditional structures in the establishment which are unlikely to be changed. In order to investigate this, Table 6 reports the results for a sample split into establishments with family ownership and those without (columns 1 and 2).

The split shows that both groups of establishments show a statistically significant and positive association between management quality and labor productivity. The size of the two coefficients is almost identical, indicating that in Germany management practices are equally important in family-owned and non-family-owned establishments. 
Another aspect we want to explore is the role of competition. Table 1 suggested that there is no direct correlation between the management score and an establishment's perception of the competition it faces. We assume that the level of competition is important to enable establishments to reap the benefits from newly implemented management techniques. There may be a source of X-inefficiency (Leibenstein, 1966), if, due to a lack of competition, the establishment is not forced to reap all potential benefits from new management procedures.

To investigate this assumption we split the establishments into two groups, based on their own assessment of the level of competition they face. ${ }^{23}$ The estimates in columns 4 and 5 are in line with our conjecture. While both groups of establishments show positive and statistically significant coefficients, the coefficient for establishments experiencing high competition is about double that for establishments in low competitive environments. This result indicates that not all establishments are able to reap the potential benefits from implementing new management practices in the same way; or that establishments in low competition contexts have no need to implement new management practices in the first place, as they do not have to measure up against fierce competition.

A Germany-specific institutional setting is the works council through which employees receive a voice in governing an establishment. The works council is tied to a legal code (Betriebsverfassungsgesetz) and has substantial rights concerning amongst others hiring and firing, bonuses and working times. In our sample, on average 38 percent of all establishments in the manufacturing industry have a works council. There is a strong relationship with firm size shown by the fact that large establishments with 250 or more employees have a works council with a probability of over 80 percent. ${ }^{24}$ In contrast, the share in small establishments with less than 50 employees is only 18 percent. In order to see how the management score is related to this institution, we separately analyze establishments with and without a works council. Following Bellmann and Ellguth (2006) we restrict the sample to establishments with a maximum of 100 employees. In these establishments other forms of worker participation are also possible and the employers face a real decision on the introduction of a works council.

The results, as presented in columns 5 and 6 of Table 6 , show that the coefficient on the management score is substantially higher in establishments with a works coun$\mathrm{cil}^{25}$, indicating that establishments with works councils seem to benefit more from the

\footnotetext{
${ }^{23}$ We define a dummy equal to one if an establishment answers "very high" to the question about the perceived level of competition it faces.

${ }^{24}$ Besides firm size, the existence of a works council is also correlated with industry, firm age, bargaining coverage, qualification structure and branch plant status (Ellguth and Trinczek, 2016).

${ }^{25}$ When we drop establishments with less than 25 employees, the management score coefficient in column (5) becomes insignificant.
} 
enforcement of good management practices. In unreported results, we dig deeper into this result by looking at the three components of the management score introduced in Table 4, i.e. incentives, targets and monitoring. We find that the results in column 6 are mainly driven by incentives, which is the only component that remains significant in the analysis with the three separate components of the management score. Considering that incentives regard promotions as well as hiring and firing, for all which the works council has a say according to the German law, the result is not surprising.

Table 6: Management and productivity: Split samples

\begin{tabular}{|c|c|c|c|c|c|c|}
\hline \multirow{3}{*}{$\begin{array}{l}\text { Dependent Variable: } \\
\text { Labor Productivity }\end{array}$} & \multicolumn{2}{|c|}{ Family ownership } & \multicolumn{2}{|c|}{ Competition } & \multicolumn{2}{|c|}{ Works council } \\
\hline & (1) & $(2)$ & (3) & $(4)$ & (5) & (6) \\
\hline & No & Yes & Low & High & No & Yes \\
\hline Management score & $\begin{array}{c}0.549 * * * \\
(0.181)\end{array}$ & $\begin{array}{c}0.540^{\star \star \star} \\
(0.155)\end{array}$ & $\begin{array}{c}0.407^{\star * \star} \\
(0.149)\end{array}$ & $\begin{array}{c}0.892^{\star \star *} \\
(0.195)\end{array}$ & $\begin{array}{l}0.384^{\star *} \\
(0.167)\end{array}$ & $\begin{array}{c}0.817^{\star \star \star} \\
(0.270)\end{array}$ \\
\hline Size (In) & $\begin{array}{l}-0.055 \\
(0.051)\end{array}$ & $\begin{array}{c}-0.099 * * \\
(0.042)\end{array}$ & $\begin{array}{c}-0.104^{\star * *} \\
(0.039)\end{array}$ & $\begin{array}{l}-0.070 \\
(0.045)\end{array}$ & $\begin{array}{c}-0.298^{\star \star \star} \\
(0.068)\end{array}$ & $\begin{array}{c}-0.473^{\star \star \star} \\
(0.103)\end{array}$ \\
\hline \multicolumn{7}{|l|}{$\begin{array}{l}\text { University degree } \\
\text { (ref: <=20\%) }\end{array}$} \\
\hline $21-40 \%$ & $\begin{array}{l}0.017 \\
(0.082)\end{array}$ & $\begin{array}{c}0.085 \\
(0.065)\end{array}$ & $\begin{array}{l}0.105^{\star} \\
(0.055)\end{array}$ & $\begin{array}{c}0.020 \\
(0.080)\end{array}$ & $\begin{array}{c}0.021 \\
(0.071)\end{array}$ & $\begin{array}{c}0.054 \\
(0.112)\end{array}$ \\
\hline $41-60 \%$ & $\begin{array}{l}0.158^{\star *} \\
(0.079)\end{array}$ & $\begin{array}{c}0.197^{\star * *} \\
(0.072)\end{array}$ & $\begin{array}{c}0.269^{\star \star \star \star} \\
(0.068)\end{array}$ & $\begin{array}{c}0.064 \\
(0.065)\end{array}$ & $\begin{array}{l}0.143^{* *} \\
(0.060)\end{array}$ & $\begin{array}{l}0.326^{\star} \\
(0.174)\end{array}$ \\
\hline $61-80 \%$ & $\begin{array}{l}0.205^{\star *} \\
(0.103)\end{array}$ & $\begin{array}{c}0.129 \\
(0.084)\end{array}$ & $\begin{array}{c}0.117 \\
(0.083)\end{array}$ & $\begin{array}{l}0.178^{*} \\
(0.098)\end{array}$ & $\begin{array}{c}0.147 \\
(0.102)\end{array}$ & $\begin{array}{l}0.254^{*} \\
(0.146)\end{array}$ \\
\hline$>80 \%$ & $\begin{array}{l}0.140^{\star} \\
(0.080)\end{array}$ & $\begin{array}{c}0.090 \\
(0.072)\end{array}$ & $\begin{array}{c}0.078 \\
(0.068)\end{array}$ & $\begin{array}{l}0.170^{\star \star} \\
(0.075)\end{array}$ & $\begin{array}{l}0.103 \\
(0.078)\end{array}$ & $\begin{array}{c}0.002 \\
(0.123)\end{array}$ \\
\hline Foreign ownership (D) & $\begin{array}{l}0.314^{\star \star \star} \\
(0.075)\end{array}$ & $\begin{array}{l}0.037 \\
(0.117)\end{array}$ & $\begin{array}{l}0.209 * * * \\
(0.080)\end{array}$ & $\begin{array}{c}0.125 \\
(0.084)\end{array}$ & $\begin{array}{c}0.193 \\
(0.135)\end{array}$ & $\begin{array}{l}0.268^{\star *} \\
(0.131)\end{array}$ \\
\hline Works council (D) & $\begin{array}{l}0.206^{\star \star \star} \\
(0.079)\end{array}$ & $\begin{array}{l}0.284^{\star \star \star} \\
(0.061)\end{array}$ & $\begin{array}{l}0.281^{* \star *} \\
(0.060)\end{array}$ & $\begin{array}{l}0.231^{\star \star \star} \\
(0.070)\end{array}$ & - & - \\
\hline Engagement abroad (D) & $\begin{array}{l}0.161^{\star \star} \\
(0.073)\end{array}$ & $\begin{array}{l}0.254^{\star \star \star} \\
(0.066)\end{array}$ & $\begin{array}{l}0.307^{* \star *} \\
(0.060)\end{array}$ & $\begin{array}{l}0.135^{\star \star} \\
(0.065)\end{array}$ & $\begin{array}{l}0.324^{\star * *} \\
(0.082)\end{array}$ & $\begin{array}{l}-0.016 \\
(0.129)\end{array}$ \\
\hline Exports (D) & $\begin{array}{c}0.020 \\
(0.070)\end{array}$ & $\begin{array}{l}0.214^{\star \star *} \\
(0.062)\end{array}$ & $\begin{array}{l}0.112^{\star} \\
(0.067)\end{array}$ & $\begin{array}{c}0.204^{\star \star *} \\
(0.067)\end{array}$ & $\begin{array}{l}0.231 * * * \\
(0.060)\end{array}$ & $\begin{array}{l}-0.062 \\
(0.141)\end{array}$ \\
\hline Obs & & 1,082 & 990 & 773 & 849 & 321 \\
\hline & & & 0.177 & 0.165 & 0.193 & 0.255 \\
\hline Adjusted R-squared & 0.182 & 0.145 & 0.156 & 0.138 & 0.170 & 0.198 \\
\hline
\end{tabular}

Notes: OLS estimations with pooled data. Clustered robust standard errors at the establishment level are in parentheses. Year dummy, industry dummies, settlement dummies and noise control included. Noise controls include gender, tenure and position of respondent as well as a dummy for answering online. $\mathrm{D}$ indicates a dummy variable. Asterisks indicate significance levels: ${ }^{\star} p<0.10,{ }^{* \star} p<0.05,{ }^{\star \star \star}$ $p<0.01$. Sample standard deviations are provided upon request.

Source: Own calculations based on GMOP. 


\section{Extensions and robustness checks}

\subsection{Establishment specific fixed effects}

The pooled OLS estimations thus far give us an idea about the contemporaneous relationship between management quality and productivity as both are measured in the same years. There is a concern that unobserved heterogeneity may bias the result, which makes it difficult to infer a causal relationship. Since the introduction of management practices is not random, but driven by optimization decisions, reverse causality is an issue to address. In order to provide a first step towards dealing with this problem, we estimate a fixed effects model as well as a model with lagged covariates.

We start with the fixed effects panel estimation. However some caution has to be exercised in the interpretation of the results as only two years of data provide limited variation over time. The results of the estimation are reported in Table 7. As expected, the coefficients for the management score decrease in size compared to the pooled OLS estimations, as fixed effects that may have previously been captured in the management score, are corrected for by the estimation technique. Reassuringly, the coefficient for the management score remains significant and positive.

Table 7: Management and productivity: Fixed effects estimation

\begin{tabular}{|c|c|c|}
\hline Dependent Variable: Labor Productivity & (1) & (2) \\
\hline Management score & $\begin{array}{l}0.198^{\star \star} \\
(0.100)\end{array}$ & $\begin{array}{c}0.259^{* * *} \\
(0.094)\end{array}$ \\
\hline Size (In) & & $\begin{array}{c}-0.222^{\star \star \star} \\
(0.051)\end{array}$ \\
\hline \multicolumn{3}{|l|}{ University degree (ref: <=20\%) } \\
\hline $21-40 \%$ & & $\begin{array}{c}0.009 \\
(0.031)\end{array}$ \\
\hline $41-60 \%$ & & $\begin{array}{c}0.046 \\
(0.055)\end{array}$ \\
\hline $61-80 \%$ & & $\begin{array}{c}0.013 \\
(0.090)\end{array}$ \\
\hline$>80 \%$ & & $\begin{array}{c}0.017 \\
(0.100)\end{array}$ \\
\hline Foreign ownership (D) & & omitted \\
\hline Works council (D) & & omitted \\
\hline Engagement abroad (D) & & $\begin{array}{c}0.012 \\
(0.043)\end{array}$ \\
\hline Exports (D) & & $\begin{array}{c}0.006 \\
(0.043)\end{array}$ \\
\hline Observations & 1,772 & 1,772 \\
\hline R-squared & 0.007 & 0.058 \\
\hline Adjusted R-squared & 0.006 & 0.053 \\
\hline Number of establishments & 956 & 956 \\
\hline
\end{tabular}

Notes: Clustered robust standard errors at the establishment level are in parentheses. Year dummy included. Industry dummies, settlement dummies and noise control omitted. D indicates a dummy variable. Asterisks indicate significance levels: ${ }^{\star} p<0.10,{ }^{* \star} p<0.05,{ }^{* \star *} p<0.01$. Sample standard deviations are provided in Table 2. Source: Own calculations based on GMOP. 
We then estimate a different variant of the empirical model where productivity is measured in 2013 while all independent variables are measured in 2008. The results, reported in Table 8, show that the importance of management quality for productivity holds. The coefficient is statistically significant, though slightly lower than the baseline estimates in Table 3. These results suggest that the higher the management quality is in 2008, the higher is an establishment's productivity in 2013.

Table 8: Management and productivity: Lagged model

\begin{tabular}{lc}
\hline Dependent Variable: Labor Productivity 2013 & \\
\hline L. Management score & $0.516^{\star \star \star}$ \\
& $(0.131)$ \\
L. Size (In) & $-0.076^{\star \star}$ \\
L. University degree: $<=20 \%$ & $(0.035)$ \\
& $-0.135^{\star *}$ \\
L. University degree: $21-40 \%$ & $(0.064)$ \\
L. University degree: $41-60 \%$ & -0.044 \\
& $(0.077)$ \\
L. University degree: $61-80 \%$ & 0.038 \\
& $(0.078)$ \\
L. University degree: $>80 \%$ & 0.024 \\
& $(0.085)$ \\
L. Foreign Ownership (D) & 0.000 \\
& $(0.000)$ \\
L. Works council (D) & $0.148^{\star *}$ \\
L. Engagement abroad (D) & $(0.060)$ \\
& $0.270^{\star \star *}$ \\
L. Exports (D) & $0.053)$ \\
& $0.199^{\star * \star}$ \\
\hline Observations & $(0.056)$ \\
R-squared & $0.147^{\star \star *}$ \\
Adjusted R-squared & $(0.056)$ \\
\hline
\end{tabular}

Notes: OLS estimation. Robust standard errors in parentheses. Industry dummies, settlement dummies and noise control included. Noise controls include gender, tenure and position of respondent as well as a dummy for answering online. $D$ indicates a dummy variable. Asterisks indicate significance levels: * $p$ $<0.10,{ }^{* \star} p<0.05,{ }^{* * \star} p<0.01$. Sample standard deviations are provided upon request.

Source: Own calculations based on GMOP.

In further robustness checks we merge the GMOP data with additional data sources. First we include establishment specific effects calculated by Card, Heining, and Kline (2013) and then we link the GMOP data to financial data provided by Bureau van Dijk.

\subsection{CHK establishment fixed effects}

Since we have only two years of data, the fixed effects estimated in Table 7 are based on limited information. Fortunately, given that the GMOP sampling frame is based on data from the $I A B$, we are able to combine our data with other data available at the $I A B$ to potentially rectify this shortcoming. In order to control for time invariant unobservable variables, we use the Card, Heining, Kline (CHK) establishment-specific fixed effects as additional regressors in a robustness check. 
CHK use administrative employee data (Integrated Employment Biographies, IEB) available at the IAB and calculate individual level wage regressions controlling for individual and establishment specific fixed effects. The latter, which we use in our robustness checks, hence reflect establishment specific wage premiums possibly capturing rent-sharing, an efficiency wage premium or strategic wage posting behavior.

The CHK effects are calculated for different periods, the most recent covering the years 2002 to 2009. In comparison to the previously estimated fixed effects model in Table 7, the CHK effects include a larger time variance and more information on the establishment, such as the skill structure. We merge these establishment level fixed effects using the plant identifier available in the administrative data and include them as an additional covariate in the baseline regression.

Since German law requires consent to linkage, this merge can only be done for establishments which specifically agreed to their survey data being linked to other data. ${ }^{26}$ This requirement reduces the sample size by about one half. Therefore, we first replicate the baseline regressions from Table 3 . Regressions shown in columns 1 and 2 of Table 9 indicate that the results are robust to the change in sample size. Columns 3 and 4 then include the CHK fixed effects. Reassuringly, the results on the management score remain robust in terms of sign, size and statistical significance. This suggests that the findings are unlikely to be driven by establishment-specific unobserved time invariant heterogeneity. In line with other empirical literature the correlation between the fixed effects (which can be interpreted as an establishment specific wage premium) and productivity is strong and significant (Bender et al., 2016; PostelVinay and Robin, 2002).

In addition, this result mitigates some of the concerns that the management score captures effects other than management practices, such as for example the general quality of the establishment. These quality effects should be captured by the CHK fixed effects so that we assume the coefficients of the management score to reflect the actual management practices.

\footnotetext{
${ }^{26}$ In their method report, Broszeit and Laible (2016) provide information on linkage possibilities of GMOP and consent rates. Further, they carry out analyses on linkage consent bias, which turned out to be negligibly small and statistically irrelevant.
} 
Table 9: Management and productivity: CHK effects

\begin{tabular}{|c|c|c|c|c|}
\hline \multirow{2}{*}{ Dependent Variable: Labor Productivity } & \multicolumn{2}{|c|}{ Without CHK } & \multicolumn{2}{|c|}{ With CHK } \\
\hline & (1) & (2) & (3) & (4) \\
\hline Management score & $\begin{array}{c}0.625^{\star \star \star} \\
(0.133)\end{array}$ & $\begin{array}{c}0.545^{\star \star *} \\
(0.140)\end{array}$ & $\begin{array}{c}0.495^{\star \star \star} \\
(0.127)\end{array}$ & $\begin{array}{c}0.511^{\star * *} \\
(0.131)\end{array}$ \\
\hline Size $(\ln )$ & & $\begin{array}{l}-0.071^{*} \\
(0.043)\end{array}$ & & $\begin{array}{c}-0.107^{\star *} \\
(0.045)\end{array}$ \\
\hline University degree (ref: <=20\%) & & & & \\
\hline $21-40 \%$ & & $\begin{array}{l}0.132^{\star *} \\
(0.065)\end{array}$ & & $\begin{array}{l}0.115^{\star} \\
(0.061)\end{array}$ \\
\hline $41-60 \%$ & & $\begin{array}{l}0.159^{\star} \\
(0.082)\end{array}$ & & $\begin{array}{c}0.130 \\
(0.080)\end{array}$ \\
\hline $61-80 \%$ & & $\begin{array}{l}0.142^{*} \\
(0.077)\end{array}$ & & $\begin{array}{c}0.067 \\
(0.074)\end{array}$ \\
\hline$>80 \%$ & & $\begin{array}{c}0.265^{\star \star \star} \\
(0.073)\end{array}$ & & $\begin{array}{c}0.232^{* \star *} \\
(0.072)\end{array}$ \\
\hline Foreign ownership (D) & & $\begin{array}{c}0.086 \\
(0.090)\end{array}$ & & $\begin{array}{c}0.076 \\
(0.090)\end{array}$ \\
\hline Works council (D) & & $\begin{array}{l}0.133^{\star \star} \\
(0.055)\end{array}$ & & $\begin{array}{c}0.075 \\
(0.053)\end{array}$ \\
\hline Engagement abroad (D) & & $\begin{array}{l}0.201^{\star \star \star} \\
(0.065)\end{array}$ & & $\begin{array}{c}0.209^{\star \star \star} \\
(0.062)\end{array}$ \\
\hline Exports (D) & & $\begin{array}{l}0.147^{\star \star} \\
(0.060)\end{array}$ & & $\begin{array}{l}0.113^{\star *} \\
(0.056)\end{array}$ \\
\hline CHK Establishment FE & & & $\begin{array}{c}1.154^{\star \star \star} \\
(0.154)\end{array}$ & $\begin{array}{c}1.088^{\star \star \star} \\
(0.178)\end{array}$ \\
\hline Year dummy & no & yes & no & yes \\
\hline Industry dummies & no & yes & no & yes \\
\hline Settlement dummies & no & yes & no & yes \\
\hline Noise controls & no & yes & no & yes \\
\hline Observations & 867 & 867 & 867 & 867 \\
\hline R-squared & 0.031 & 0.162 & 0.123 & 0.228 \\
\hline Adjusted R-squared & 0.030 & 0.138 & 0.121 & 0.205 \\
\hline
\end{tabular}

Notes: OLS estimations with pooled data. Only establishments from West Germany. Clustered robust standard errors at the establishment level are in parentheses. Noise controls include gender, tenure and position of respondent as well as a dummy for answering online. $\mathrm{D}$ indicates a dummy variable. Asterisks indicate significance levels: ${ }^{*} p<0.10,{ }^{* *} p<0.05,{ }^{* \star *} p<0.01$. Sample standard deviations are provided upon request.

Source: Own calculations based on GMOP linked with CHK.

\subsection{Additional outcome variables: Bureau van Dijk}

Due to the sampling strategy, we are also able to link the GMOP to data from Bureau van Dijk. This commercial data provider specializes in the provision of financial information. BvD mainly sources its information from Creditreform who in turn collect data from the e-Bundesanzeiger, an official information platform of the German government where firms have to submit their annual reports. This link allows us to analyze the effects of management practices at the firm level instead of the establishment level. We can thus use two additional dependent variables as alternatives to labor productivity, namely, operating revenue per employee and sales per employee. Furthermore, the BvD data provides a measure of capital, which can be included as further control in the regressions. 
As with the CHK merge, the link of GMOP and BvD can only be done for establishments who consented to linkage. We further lose observations due to a revised linkage strategy between the BHP and BvD (Antoni et al., 2016), as well as missing data in BvD. We further have to deal with another data caveat, namely, the fact that we do not have financial data for 2013. Therefore, we can only use the management index for 2008 and cannot estimate a fixed effects model. However, we can estimate separate lagged models for 2009, 2010 and 2011 respectively. The results can be found in Table $10 .{ }^{27}$

Table 10: Management and productivity: Estimations with BvD data

\begin{tabular}{|c|c|c|c|c|c|c|}
\hline \multirow[b]{2}{*}{ Dependent Variables: } & \multicolumn{2}{|c|}{2009} & \multicolumn{2}{|c|}{2010} & \multicolumn{2}{|c|}{2011} \\
\hline & $\begin{array}{l}\quad(1) \\
\text { Operating } \\
\text { Revenue }\end{array}$ & $\begin{array}{c}(2) \\
\text { Sales }\end{array}$ & $\begin{array}{c}\text { (3) } \\
\text { Operating } \\
\text { Revenue }\end{array}$ & $\begin{array}{c}(4) \\
\text { Sales }\end{array}$ & $\begin{array}{c}\text { (5) } \\
\text { Operating } \\
\text { Revenue }\end{array}$ & $\begin{array}{c}(6) \\
\text { Sales }\end{array}$ \\
\hline L.Management score & $\begin{array}{l}0.436^{*} \\
(0.224)\end{array}$ & $\begin{array}{l}0.435^{\star} \\
(0.229)\end{array}$ & $\begin{array}{l}0.424^{*} \\
(0.255)\end{array}$ & $\begin{array}{c}0.554^{\star \star *} \\
(0.211)\end{array}$ & $\begin{array}{c}0.583^{\star \star *} \\
(0.213)\end{array}$ & $\begin{array}{c}0.603^{\star * *} \\
(0.208)\end{array}$ \\
\hline L.Labor (In) & $\begin{array}{c}0.009 \\
(0.053)\end{array}$ & $\begin{array}{l}-0.002 \\
(0.052)\end{array}$ & $\begin{array}{l}0.068 \\
(0.053)\end{array}$ & $\begin{array}{c}0.049 \\
(0.051)\end{array}$ & $\begin{array}{c}0.054 \\
(0.049)\end{array}$ & $\begin{array}{l}0.043 \\
(0.050)\end{array}$ \\
\hline L.Capital (In) & $\begin{array}{l}0.074^{\star \star \star} \\
(0.028)\end{array}$ & $\begin{array}{l}0.071^{\star \star} \\
(0.028)\end{array}$ & $\begin{array}{c}0.110^{\star \star \star *} \\
(0.031)\end{array}$ & $\begin{array}{c}0.091^{\star \star \star} \\
(0.027)\end{array}$ & $\begin{array}{l}0.109 * \star \star \\
(0.028)\end{array}$ & $\begin{array}{l}0.108^{\star \star \star} \\
(0.027)\end{array}$ \\
\hline $\begin{array}{l}\text { L.University degree } \\
\text { (ref.: <=20\%) }\end{array}$ & & & & & & \\
\hline $21-40 \%$ & $\begin{array}{l}0.250^{\star *} \\
(0.121)\end{array}$ & $\begin{array}{l}0.263^{\star *} \\
(0.123)\end{array}$ & $\begin{array}{c}0.202 \\
(0.131)\end{array}$ & $\begin{array}{c}0.158 \\
(0.113)\end{array}$ & $\begin{array}{l}0.203^{*} \\
(0.118)\end{array}$ & $\begin{array}{c}0.189 \\
(0.118)\end{array}$ \\
\hline $41-60 \%$ & $\begin{array}{c}0.167 \\
(0.104)\end{array}$ & $\begin{array}{l}0.159 \\
(0.106)\end{array}$ & $\begin{array}{l}0.097 \\
(0.124)\end{array}$ & $\begin{array}{c}0.023 \\
(0.109)\end{array}$ & $\begin{array}{c}0.120 \\
(0.092)\end{array}$ & $\begin{array}{c}0.116 \\
(0.093)\end{array}$ \\
\hline $61-80 \%$ & $\begin{array}{l}-0.021 \\
(0.114)\end{array}$ & $\begin{array}{l}-0.024 \\
(0.114)\end{array}$ & $\begin{array}{l}0.061 \\
(0.139)\end{array}$ & $\begin{array}{l}0.017 \\
(0.126)\end{array}$ & $\begin{array}{l}-0.029 \\
(0.121)\end{array}$ & $\begin{array}{l}-0.061 \\
(0.120)\end{array}$ \\
\hline$>80 \%$ & $\begin{array}{l}0.259^{* *} \\
(0.116)\end{array}$ & $\begin{array}{l}0.203^{*} \\
(0.119)\end{array}$ & $\begin{array}{l}0.206 \\
(0.129)\end{array}$ & $\begin{array}{c}0.114 \\
(0.112)\end{array}$ & $\begin{array}{l}0.166 \\
(0.118)\end{array}$ & $\begin{array}{l}0.107 \\
(0.122)\end{array}$ \\
\hline L.Foreign ownership (D) & $\begin{array}{l}0.247^{\star *} \\
(0.115)\end{array}$ & $\begin{array}{l}0.246^{\star \star} \\
(0.115)\end{array}$ & $\begin{array}{l}0.306^{* *} \\
(0.129)\end{array}$ & $\begin{array}{l}0.221^{\star *} \\
(0.098)\end{array}$ & $\begin{array}{l}0.241^{\star *} \\
(0.100)\end{array}$ & $\begin{array}{l}0.245^{\star *} \\
(0.102)\end{array}$ \\
\hline L.Works council (D) & $\begin{array}{c}0.142 \\
(0.094)\end{array}$ & $\begin{array}{l}0.148 \\
(0.096)\end{array}$ & $\begin{array}{c}0.023 \\
(0.132)\end{array}$ & $\begin{array}{c}0.119 \\
(0.085)\end{array}$ & $\begin{array}{c}0.094 \\
(0.085)\end{array}$ & $\begin{array}{c}0.085 \\
(0.086)\end{array}$ \\
\hline L.Engagement abroad (D) & $\begin{array}{c}0.049 \\
(0.089)\end{array}$ & $\begin{array}{l}0.055 \\
(0.089)\end{array}$ & $\begin{array}{c}0.027 \\
(0.099)\end{array}$ & $\begin{array}{l}-0.012 \\
(0.084)\end{array}$ & $\begin{array}{l}-0.072 \\
(0.089)\end{array}$ & $\begin{array}{l}-0.061 \\
(0.089)\end{array}$ \\
\hline L.Exports (D) & $\begin{array}{c}0.159 \\
(0.106)\end{array}$ & $\begin{array}{l}0.136 \\
(0.110)\end{array}$ & $\begin{array}{l}0.244^{\star *} \\
(0.116)\end{array}$ & $\begin{array}{l}0.288^{\star * *} \\
(0.110)\end{array}$ & $\begin{array}{l}0.290^{* *} \\
(0.117)\end{array}$ & $\begin{array}{l}0.282^{\star \star} \\
(0.121)\end{array}$ \\
\hline Observations & 286 & 286 & 269 & 268 & 267 & 267 \\
\hline R-squared & 0.268 & 0.253 & 0.301 & 0.373 & 0.414 & 0.390 \\
\hline Adjusted R-squared & 0.201 & 0.185 & 0.232 & 0.311 & 0.356 & 0.330 \\
\hline
\end{tabular}

Notes: OLS estimations with lagged independent variable. Dependent variables are calculated per employee. All independent variables refer to 2008. Operating Revenue, Sales, Labor and Capital are taken from BvD. Robust standard errors are in parentheses. Industry dummies, settlement dummies and noise control included. Noise controls include gender, tenure and position of respondent as well as a dummy for answering online. $D$ indicates a dummy variable. Asterisks indicate significance levels: * $p$ $<0.10,{ }^{* \star} p<0.05,{ }^{* \star *} p<0.01$. Sample standard deviations are provided upon request.

Source: Own calculations based on GMOP linked with BvD.

${ }^{27}$ Due to the small number of remaining observations as well as the consolidation at the firm level, the representativeness of the BvD sample is not entirely assured. 
The results point to a robust positive relationship between management quality and the investigated outcome variables. Although the models are considerably reduced in the number of observations, the magnitude and significance of the management score remains very close, albeit a bit smaller, compared to the coefficients in the baseline model in Table 3. This is even more reassuring, as we are now able to include capital in the productivity equations. Table A3 of the appendix A4 shows additional results when capital is not included in the BvD estimations. For these estimations the number of observations increases due to missing data in the capital variable; the main observed pattern of Table 10 remains the same, however, giving further indication for robustness. Moreover, a pattern emerges, where increasing lags lead to larger management score coefficients, both for operating revenue and sales as dependent variables. It seems that having a good management structure in 2008 leads to an increasingly higher firm performance in subsequent years.

\section{Discussion and conclusion}

The "German Management and Organizational Practices" (GMOP) Survey presents a new tool for examining the link between management and firm performance for a large sample of establishments. The survey is closely modeled on the US "Management and Organizational Practices Survey" (Bloom et al., 2013), which allows comparisons between these two countries. This paper introduces the survey and provides first evidence on the dissemination of management practices as well as the link between management and labor productivity in Germany.

As pointed out, the data only provide two observations per firm. Hence, we do not have a large time series per establishment which would help to sort out causality. Also, given the nature of the management-productivity relationship we investigate, it is difficult to implement instruments in management surveys (see also Bloom et al., 2013). Therefore, the evidence should be regarded as the result of initial attempts to determine correlations in a novel dataset, with a number of steps taken to get closer to causal relationships. However, we take confidence from recent field experiments that suggest a causal mechanism between new management practices and increased performance (Bloom, Liang, Roberts, \& Ying, 2015; Jackson \& Schneider, 2015). The same relationship is advocated by "insider econometrics", which additionally assumes that individual management practices on their own may have no effect, but that a bundle of practices does (Ichniowski and Shaw, 2003). Hence, we cautiously suggest that at least part of the statistical correlations we uncover reflect causation.

The analyses show that the quality of management, measured by a management score, has increased among German establishments between 2008 and 2013, but still lags behind a comparable measure for the US. We find that there is a positive association between management score and productivity. However, the strength of this statistical association also appears lower in Germany than in the US. While not providing unequivocally proof, this result suggests that lower management quality in Germany may partly explain the persistent productivity gap between Germany and 
the US in the last two decades (e.g., OECD, 2015). We can only speculate on the reasons for the lower management quality in Germany. It is conceivable that the relatively lower labor market flexibility in Germany prevents or hinders the use of some management practices concerning human resources, e.g., hiring and firing, promotion or bonuses. Additionally, higher levels of collective bargaining, union coverage and works councils may have similar dampening effects. Regarding the comparability of the management scores between Germany and the US validity tests should be carried out. Although we did the best possible to be as close as possible to the original meaning of the questions, we cannot state with absolute certainty that all items really measure what they are meant to. A detailed comparative study could help to provide clarity. Together with this, a thorough explanation of the cross-country differences and the implications for aggregate productivity remains.

The data show considerable heterogeneity across establishments in terms of management practices. In particular, we find that establishment size matters. In line with the international literature (e.g., Bloom et al., 2013), the management score is substantially higher for large establishments compared to small establishments on average. Additionally, the link between management and productivity is stronger for the former. On the one hand, differences in management scores between firm sizes in Germany may be due to a lack of necessity for the surveyed management techniques, i.e. structured rules can be neglected and decisions are made for individual employees in small establishments, but not in larger ones. On the other hand, the cost of implementing management practices may simply be too high.

In this context it should be pointed out that the powerhouse of the German manufacturing industry is the Mittelstand, i.e., small and medium sized establishments. Given the comparatively low level of management scores for these types of establishments, there is substantial potential for catching up. Improving management practices among this group of establishments could lead to gains in productivity, even if these may be relatively lower than those reaped by large establishments. This apparent underperformance of small and medium sized firms may also be part of an explanation for the productivity differences observed between Germany and the US. It also links to a broader international debate on growing productivity dispersion. Andrews, Criscuolo, and Gal (2015) present suggestive evidence that growth among technologically leading firms remained robust in recent years, but aggregate productivity in advanced economies, also Germany, has been slowing down. Increasing productivity dispersion could result from insufficient absorptive capacity of lagging firms to learn from frontier firms. Future research might therefore explore to what extent management practices, as a form of tacit knowledge of the production process, diffuse too slowly among firms and whether complementary investment, e.g. computerized information, can help mitigate this process (OECD, 2015). 


\section{Bibliography}

Andrews, D., Criscuolo, C., \& Gal, P. (2015): Frontier Firms, Technology Diffusion and Public Policy: Micro Evidence from OECD Countries (No. 2), OECD Publishing.

Antoni, M., Koller, K., Laible, M.-C., \& Zimmermann, F. (2016): From Key to Dataset, forthcoming.

Bandiera, O., Barankay, I., \& Rasul, I. (2005): Social Preferences and the Response to Incentives: Evidence from Personnel Data. The Quarterly Journal of Economics, 120(3), 917-962.

Bandiera, O., Barankay, I., \& Rasul, I. (2007): Incentives for Managers and Inequality among Workers: Evidence from a Firm-Level Experiment. The Quarterly Journal of Economics, 122(2), 729-773.

Bellmann, L. \& Ellguth, P. (2006): Verbreitung von Betriebsräten und ihr Einfluss auf die betriebliche Weiterbildung/Works Council Presence and Impact on Training of the Workforce. Jahrbücher für Nationalökonomie und Statistik, 487-504.

Bellmann, L. \& Hübler, O. (2015): Working time accounts and firm performance in Germany. IZA Journal of European Labor Studies, 4(1), 1.

Bender, S., Bloom, N., Card, D., van Reenen, J., \& Wolter, S. (2016): Management Practices, Workforce Selection and Productivity. CEP Discussion Paper, no. 1416, $57 \mathrm{p}$.

Bloom, N., Brynjolfsson, E., Foster, L., Jarmin, R., Saporta-Eksten, I., \& van Reenen, J. (2013): Management in America. Center for Economic Studies, U.S. Census Bureau, 13-01.

Bloom, N., Lemos, R., Sadun, R., Scur, D., \& van Reenen, J. (2016): International Data on Measuring Management Practices. American Economic Review, 106(5), 152-56.

Bloom, N., Liang, J., Roberts, J., \& Ying, Z. J. (2015): Does Working from Home Work? Evidence from a Chinese Experiment. The Quarterly Journal of Economics, 130(1), 165-218.

Bloom, N. \& van Reenen, J. (2007): Measuring and Explaining Management Practices Across Firms and Countries. The Quarterly Journal of Economics, 122(4), 13511408.

Bloom, N. \& van Reenen, J. (2010): Why Do Management Practices Differ across Firms and Countries? Journal of Economic Perspectives, 24(1), 203-224.

Böckerman, P. \& Ilmakunnas, P. (2012): The job satisfaction-productivity nexus: A study using matched survey and register data. Industrial \& Labor Relations Review, 65(2), 244-262.

Broszeit, S. \& Laible, M.-C. (2016): The German Management and Organizational Practices (GMOP) Survey, FDZ-Methodenreport, Nürnberg, forthcoming.

Burgess, S., Propper, C., Ratto, M., Scholder, K., von Hinke, S., \& Tominey, E. (2010): Smarter Task Assignment or Greater Effort: The Impact of Incentives on Team Performance. The Economic Journal, 120(547), 968-989. 
Brynjolfsson, E. \& McElheran, K. (2016): Data in Action: Data-Driven Decision Making in US Manufacturing. US Census Bureau Center for Economic Studies Paper No. CES-WP-16-06.

Card, D., Heining, J., \& Kline, P. (2013): Workplace Heterogeneity and the Rise of West German Wage Inequality. The Quarterly Journal of Economics, 128(3), 9671015.

Datta, D. K., Guthrie, J. P., \& Wright, P. M. (2005): Human Resource Management and Labor Productivity: Does Industry Matter? Academy of Management Journal, 48(1), 135-145.

Ellguth, P. \& Trinczek, R. (2016): Erosion der betrieblichen Mitbestimmung - Welche Rolle spielt der Strukturwandel? WSI-Mitteilungen, 69(3), 172-182.

European Commission. (2016): What is an SME? Retrieved 12/04/2016 http://ec.europa.eu/growth/smes/business-friendly-environment/smedefinition/index en.htm.

Federal Ministry of Economics and Technology (2013): German Mittelstand: Engine of the German economy. Retrieved 15/02/2016 https://www.bmwi.de/English/Redaktion/Pdf/factbook-germanmittelstand,property=pdf,bereich=bmwi2012,sprache=en, rwb=true.pdf.

Gruhl, A., Schmucker, A., \& Seth, S. (2012): The Establishment History Panel 19752010: Handbook version 2.2. 1. Institut für Arbeitsmarkt-und Berufsforschung (IAB), Nürnberg [Institute for Employment Research, Nuremberg, Germany].

Helpman, E., Melitz, M. J., \& Yeaple, S. R. (2004): Export Versus FDI with Heterogeneous Firms. American Economic Review, 94(1), 300-316.

Huselid, M. A. (1995): The Impact Of Human Resource Management Practices On Turnover, Productivity, And Corporate Financial Performance. Academy of Management Journal, 38(3), 635-672.

Ichniowski, C. \& Shaw, K. (2003): Beyond Incentive Pay: Insiders' Estimates of the Value of Complementary Human Resource Mangement Practices. The Journal of Economic Perspectives, 17(1), 155-180.

Jackson, C. K. \& Schneider, H. S. (2015): Checklists and Worker Behavior: A Field Experiment. American Economic Journal: Applied Economics, 7(4), 136-168.

Lazear, E. P. (2000): Performance Pay and Productivity. American Economic Review, 90(5), 1346-1361.

Leibenstein, H. (1966): Allocative efficiency vs. 'X-Efficiency'. The American Economic Review, 56(3), 392-415.

Lin, H. C. \& Shih, C. T. (2008): How Executive SHRM System Links to Firm Performance: The Perspectives of Upper Echelon and Competitive Dynamics. Journal of Management, 34(5), 853-881.

Mundlak, Y. (1961): Empirical Production Function Free of Management Bias. Journal of Farm Economics, 43(1), 44-56. 
Nagin, D. S., Rebitzer, J. B., Sanders, S., \& Taylor, L. J. (2002): Monitoring, motivation and management: The determinants of opportunistic behavior in a field experiment. The American Economic Review, 92(4), 850-873.

OECD (2015): The Future of Productivity, OECD Publishing, Paris.

Postel-Vinay, F. \& Robin, J. M. (2002): Equilibrium Wage Dispersion with Worker and Employer Heterogeneity, Econometrica, 70(6), 2295-2350.

van Reenen, J. (2011): Does competition raise productivity through improving management quality? International Journal of Industrial Organization, 29(3), 306-316.

Roeger, W., Varga, J., \& in 't Veld, J. (2010): How to close the productivity gap between the US and Europe: A quantitative assessment using a semi-endogenous growth model. European Economy - Economic Papers, Directorate General Economic and Financial Affairs (DG ECFIN), European Commission, 399.

Schild, C.-J. (2016): Linking "Orbis" Company Data with Establishment Data from the German Federal Employment Agency, forthcoming.

Shaw, K. (2009): Insider Econometrics: A roadmap with Stops Along the Way. Labour Economics, 16, 607-617.

Syverson, C. (2011): What Determines Productivity? Journal of Economic Literature, 49(2), 326-365.

Tomaskovic-Devey, D., Leiter, J., \& Thompson, S. (1995): Item Nonresponse in Organizational Surveys. Sociological Methodology, 25, 77-110. 


\section{Appendix}

\section{A1 Survey details and data quality}

Conduction and survey design: The survey was carried out jointly by two research institutions, the IfW and the IAB and infas, a company highly experienced in running large-scale surveys. The original US MOPS survey format was carried over by conducting all interviews by paper-pencil or online and by keeping to the questionnaire and survey design of the MOPS.

Respondents: We define the target respondent as top manager, i.e. managing director, CEO, division or plant manager. We believe that this respondent group has the best overview of the establishment's processes and structures and can thus give better information both on the use of management practices and performance measures (Tomaskovic-Devey, Leiter, and Thompson, 1995). Over 90 percent of all completed surveys were answered by the target group. ${ }^{28}$ The respondents have an average tenure of 17 years and about 80 percent are male.

Sample design: The GMOP population consists of German establishments in the manufacturing industry with 25 or more employees liable to social security. A disproportional stratified random gross sample design based on sub-industries, firm sizes and settlement structures was chosen. The sample was drawn from the Employment History Panel (BHP) 2011, which includes all German establishments with at least one employee liable to social security (Gruhl, Schmucker, and Seth, 2012), with the restriction that a valid link between the BHP and firm-level Bureau van Dijk data had to exist (Antoni et al., 2016). This strategy was chosen to enable joint analysis on the firm and establishment level. Further restricting the BHP-BvD population to establishments in the manufacturing industry with more than 25 employees, the target population consists of 54,610 establishments. From these, a gross sample of 32,847 establishments was drawn for the GMOP survey.

Completed surveys and recall bias: The field phase lasted from November 2014 to May 2015 and several reminders were sent to the establishments during this time. In the end, 1,927 complete interviews, covering the years 2008 and 2013 were collected.

\footnotetext{
${ }^{28} 65$ percent of the respondents are executive officers, 4 percent are managers of multiple establishments, 10 percent managers of one establishment and 11 percent managers within an establishment. 3 percent of the respondents were not managers.
} 
All answers in the questionnaire were based on recall. An analysis comparing administrative establishment level data from the IAB and the GMOP did indicate that a possible recall bias kept within acceptable limits (Broszeit and Laible, 2016).

Response rates: The overall response rate is 6 percent. A comparison of response rates within the stratification variables, size, industry and settlement shows that the participating establishments are spread rather equally across the strata. The main deviations can be observed for small establishments with 25 to 49 employees, which are slightly underrepresented while the larger establishments are slightly overrepresented. While establishments from "industrial goods" are overrepresented, those from "construction" are underrepresented. No notable differences occur regarding the settlement structure.

Survey representativeness: Several analyses indicate that the survey is representative (Broszeit and Laible, 2016). Comparing participating establishments with all establishments in the target population based on data from the BHP reveals that only small deviations occur, for example concerning the qualification structure. The GMOP establishments have slightly better qualified employees compared to the total population. However, the observed significant differences are very small. Furthermore, no significant differences are observed for the share of females, the share of trainees, the employee age structure or the establishment age.

When using sampling weights, which correct for the sample drawing design, the GMOP participants' means quite accurately align to the means of the total population. This indicates that the differences are not severe and that deviations can be accounted for by using weights. We therefore use weights for descriptive statistics and include the stratification variables in our multivariate regressions.

Unit non-response: Unit non-response is investigated in Broszeit and Laible (2016). They conduct a multivariate selectivity analysis, which shows whether the variables above significantly influence the willingness to take part in the survey. Their estimates do not indicate any serious concerns in terms of systematic bias due to non-response. They conclude that, overall, systematic unit non-response is unlikely to affect the estimation results via biases incurred by the lack of participation of some establishments.

Consent to linkage: Explicit permission is a mandatory prerequisite for merging survey data to other (administrative) data in Germany. 53 percent of the GMOP respondents consented to linkage with data available at the IAB, such that 1,021 establishment observations can be used for joint analysis with other data sets. 
Representativeness of the regression sample: As we lose observations due to missing values in single variables and the dropping of productivity outliers, we provide evidence for the representativeness of the regression sample. Given that the sampling design is based on administrative data from the IAB, we have information on serval establishment characteristics for the whole target group. We refer the representativeness analyses to the year 2014 , the beginning of the survey field phase, in which the target population amounts to 50,624 establishments.

Table A1 shows both the probability of taking part in the survey (column 1) and of being included in the analytic estimations (column 2). In column 1 the dependent variable takes the value one if the establishment completed the GMOP survey and was found in the BHP 2014 data. This is true for 1,877 establishments. In column 2 the dependent variable is one, if the establishment is in the regression sample, which applies to 932 establishments. Excluded are observations that had to be dropped due to missing values or data cleaning processes.

The estimations show that the share of qualified employees, the share of trainees as well as median wages significantly influence the outcome variables of both columns. However, the estimates are small in size and do not significantly differ between column 1 and 2. We thus regard the regression sample to be unbiased. Further information on the target population as well as evidence for the representativeness of the full data is provided by Broszeit and Laible (2016).

Table A1: Representativeness of the regression sample

\begin{tabular}{lccccccc}
\hline & \multicolumn{3}{c}{$(1)$} & \multicolumn{3}{c}{$(2)$} \\
Dependent variables & GMOP participant (D) & \multicolumn{3}{c}{ GMOP regression sample (D) } \\
\hline Female employees (share) & 0.00 & $(0.00)$ & & -0.00 & $(0.00)$ & \\
Qualified employees (share) & 0.03 & $(0.01)$ & $* \star *$ & 0.02 & $(0.01)$ & $* \star *$ \\
Trainees/apprentices (share) & 0.08 & $(0.02)$ & $* * *$ & 0.04 & $(0.01)$ & $* * *$ \\
Mean age of employees & 0.00 & $(0.00)$ & & 0.00 & $(0.00)$ \\
Median wage of employees & -0.00 & $(0.00)$ & $* * *$ & -0.00 & $(0.00)$ & $* * *$ \\
Age of establishment & -0.00 & $(0.00)$ & & -0.00 & $(0.00)$ \\
Employment development (ref: no change) & & & & & \\
$\quad$ Increase in employment & 0.00 & $(0.00)$ & & 0.00 & $(0.00)$ \\
Decrease in employment & 0.00 & $(0.00)$ & & 0.00 & $(0.00)$ \\
\hline
\end{tabular}

\begin{tabular}{|c|c|c|}
\hline F-Tests: & & \\
\hline Size strata & $\operatorname{chi} 2(2)=70.06 ; p=0.000$ & $\operatorname{chi} 2(2)=53.90 ; p=0.000$ \\
\hline Industry strata & $\operatorname{chi} 2(4)=81.20 ; p=0.000$ & $\operatorname{chi} 2(4)=43.16 ; p=0.000$ \\
\hline Settlement strata & $\operatorname{chi} 2(3)=8.46 ; \quad p=0.037$ & $\operatorname{chi} 2(3)=5.51 ; \quad p=0.138$ \\
\hline Observations total & 50,624 & 50,624 \\
\hline GMOP participants & 1,877 & - \\
\hline GMOP regression sample & - & 932 \\
\hline Pseudo R-squared & 0.013 & 0.014 \\
\hline
\end{tabular}

Notes: Probit regressions. Average marginal effects. Robust standard errors in parentheses. D indicates a dummy variable. Asterisks indicate significance levels: * $p<0.10,{ }^{* \star} p<0.05,{ }^{* \star} p<0.01$.

Source: Own calculations based on GMOP and BHP 2014. 


\section{A2 Variables overview}

Table A2: Variables in the regression

\begin{tabular}{|c|c|c|}
\hline Variable & Source & Question / Definition \\
\hline $\begin{array}{l}\text { Management } \\
\text { score }\end{array}$ & Generated & $\begin{array}{l}\text { Score between } 0 \text { and } 1 \text { based on } 16 \text { questions on management practices } \\
\text { (following Bloom et al., 2013) }\end{array}$ \\
\hline Employees & Generated & $\begin{array}{l}\text { Sum of managers and non-managers that were employed at this establish- } \\
\text { ment on the reference date } 30 \text { June }\end{array}$ \\
\hline Size (In) & Generated & Natural logarithm of Employees \\
\hline Productivity (In) & Generated & $\begin{array}{l}\text { Natural logarithm of (Sales-Intermediates)/Employee } \\
-\quad \text { What were your total annual sales (exclusive of value added tax)? } \\
\text { - What share of sales was attributed to intermediate inputs and external } \\
\text { costs? These are all raw materials and supplies, commodities, wage } \\
\text { work, external services, rents and other costs that were purchased from } \\
\text { other companies or facilities. }\end{array}$ \\
\hline $\begin{array}{l}\text { Managers: } \\
\text { university de- } \\
\text { gree }\end{array}$ & Questionnaire & $\begin{array}{l}\text { What was the percentage of managers at this establishment with a univer- } \\
\text { sity degree? } \\
\begin{array}{l}\text { - } \\
\text { - }\end{array} 21 \text { to } 40 \% \\
\text { - } 41 \text { to } 60 \% \\
\text { - } 61 \text { to } 80 \% \\
\text { - } \quad \text { More than } 80 \% \\
\end{array}$ \\
\hline $\begin{array}{l}\text { Non-managers: } \\
\text { university de- } \\
\text { gree }\end{array}$ & Questionnaire & $\begin{array}{l}\text { What was the percentage of non-managers at this establishment with a uni- } \\
\text { versity degree? } \\
\text { - } 10 \% \text { or less } \\
\text { - } 11 \text { to } 20 \% \\
\text { - } \quad \text { More than } 20 \%\end{array}$ \\
\hline $\begin{array}{l}\text { Foreign } \\
\text { ownership (D) }\end{array}$ & Questionnaire & $\begin{array}{l}\text { Is your establishment mainly or exclusively... } \\
\text { - } \quad \text { German property } \\
\text { - } \quad \text { foreign property } \\
\text { - } \quad \text { equally divided into German and foreign property } \\
\end{array}$ \\
\hline $\begin{array}{l}\text { Family } \\
\text { ownership (D) }\end{array}$ & Questionnaire & $\begin{array}{l}\text { Was the principal owner of this establishment a family? } \\
\text { - Yes } \\
\text { - No }\end{array}$ \\
\hline $\begin{array}{l}\text { Works } \\
\text { council (D) }\end{array}$ & Questionnaire & $\begin{array}{l}\text { Does this establishment have a works council? } \\
\text { - Yes } \\
\text { - No }\end{array}$ \\
\hline $\begin{array}{l}\text { Engagement } \\
\text { abroad (D) }\end{array}$ & Questionnaire & $\begin{array}{l}\text { Was your establishment active abroad? This includes taking over of a } \\
\text { company abroad, setting up a location or subsidiary abroad or an equity } \\
\text { participation amounting to a minimum of } 10 \% \text { of foreign companies. } \\
\text { - Yes } \\
\text { - No }\end{array}$ \\
\hline Exports (D) & Questionnaire & $\begin{array}{l}\text { Did this firm export? } \\
\text { - Yes } \\
\text { - No }\end{array}$ \\
\hline Competition (D) & Questionnaire & $\begin{array}{l}\text { How do you rate the pressure from competition that your establishment } \\
\text { was exposed to? } \\
\text { - very low } \\
\text { - rather low } \\
\text { - } \text { rather high } \\
\text { - very high }\end{array}$ \\
\hline
\end{tabular}

Notes: Bold letters indicate that the dummy takes the value one for these categories. 


\section{A3 Additional Figures}

Figure A1: Splitting up the indicator: Germany and the US
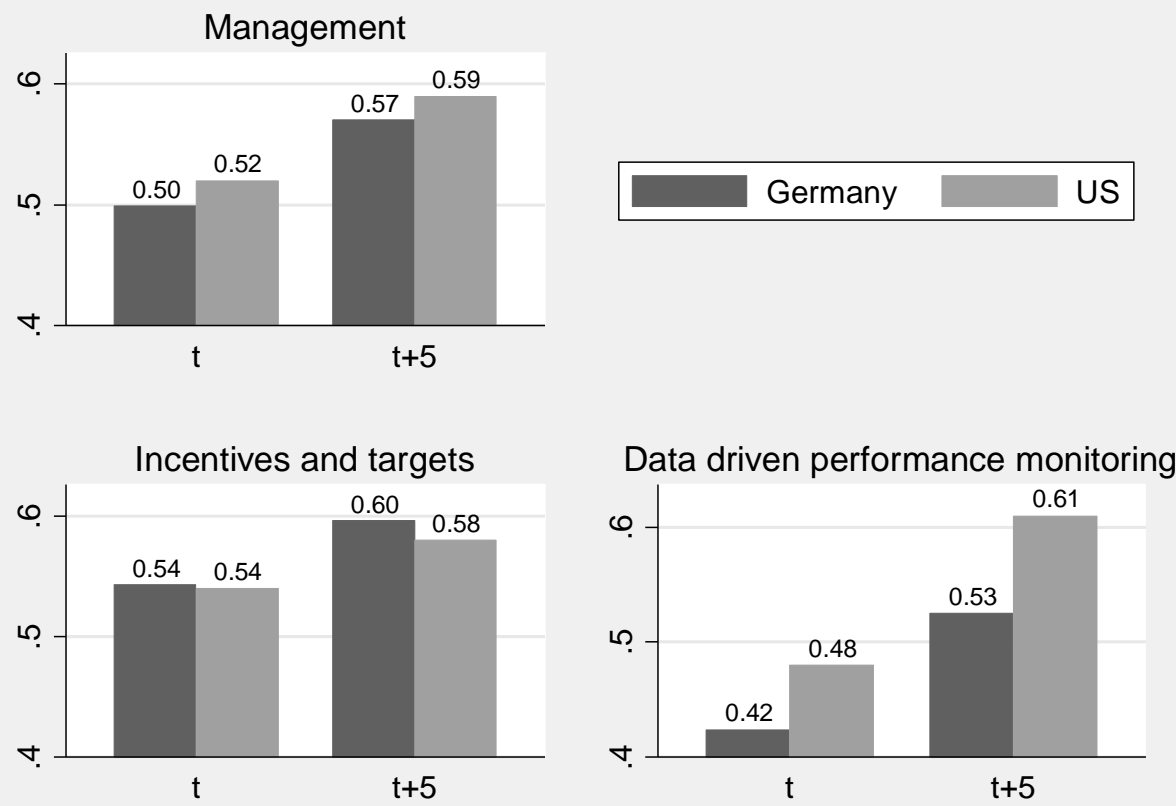

Notes: Weighted observations. Note that t relates to 2008 for Germany and 2005 for the US. Source: Own calculations based on GMOP. Values for the US are retrieved from Figure 5 in Bloom et al. (2013).

Figure A2: Splitting up the indicator: Firm sizes
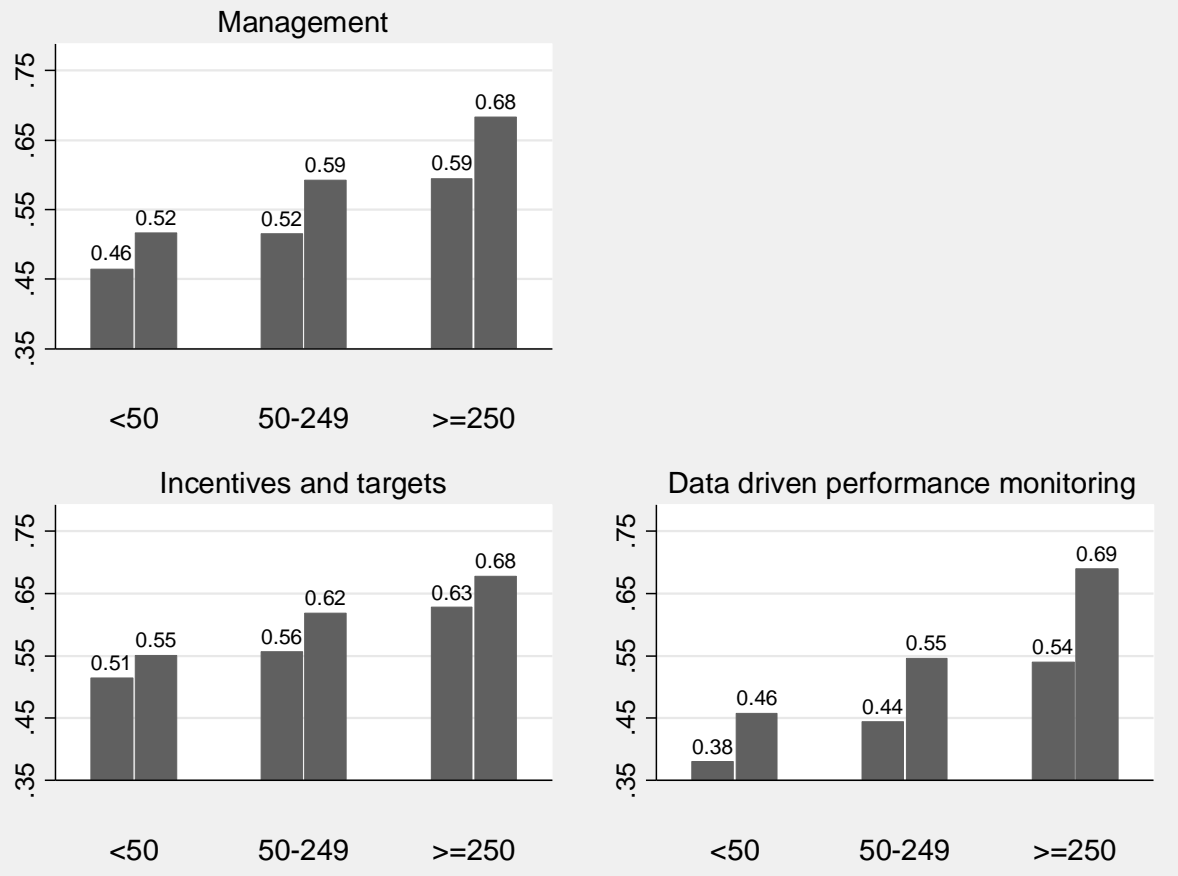

Notes: Weighted observations. The first bar respectively relates to 2008, the second bar to 2013 . Source: Own calculations based on GMOP. 


\section{A4 BvD Estimation}

Table A3: Productivity estimations with BvD data (not controlled for capital)

\begin{tabular}{|c|c|c|c|c|c|c|}
\hline \multirow[b]{2}{*}{ Dependent Variables: } & \multicolumn{2}{|c|}{2009} & \multicolumn{2}{|c|}{2010} & \multicolumn{2}{|c|}{2011} \\
\hline & $\begin{array}{c}\text { (1) } \\
\text { Operating } \\
\text { Revenue }\end{array}$ & Sales & $\begin{array}{c}\text { (3) } \\
\text { Operating } \\
\text { Revenue }\end{array}$ & $\begin{array}{c}(4) \\
\text { Sales }\end{array}$ & $\begin{array}{c}\text { (5) } \\
\text { Operating } \\
\text { Revenue }\end{array}$ & $\begin{array}{c}(6) \\
\text { Sales }\end{array}$ \\
\hline L.Management score & $\begin{array}{l}0.489^{\star \star} \\
(0.199)\end{array}$ & $\begin{array}{l}0.432^{*} \\
(0.221)\end{array}$ & $\begin{array}{l}0.469^{\star *} \\
(0.229)\end{array}$ & $\begin{array}{c}0.585^{\star \star \star} \\
(0.209)\end{array}$ & $\begin{array}{c}0.563^{\star \star *} \\
(0.200)\end{array}$ & $\begin{array}{c}0.636^{\star \star \star} \\
(0.204)\end{array}$ \\
\hline L.Labor (In) & $\begin{array}{c}0.001 \\
(0.047)\end{array}$ & $\begin{array}{l}-0.005 \\
(0.050)\end{array}$ & $\begin{array}{l}0.063 \\
(0.048)\end{array}$ & $\begin{array}{c}0.046 \\
(0.050)\end{array}$ & $\begin{array}{c}0.013 \\
(0.052)\end{array}$ & $\begin{array}{c}0.039 \\
(0.050)\end{array}$ \\
\hline \multicolumn{7}{|l|}{$\begin{array}{l}\text { L.University degree } \\
\text { (ref.: <=20\%) }\end{array}$} \\
\hline $21-40 \%$ & $\begin{array}{l}0.291 * \star \star \\
(0.112)\end{array}$ & $\begin{array}{l}0.339 * \star \star \\
(0.119)\end{array}$ & $\begin{array}{l}0.298^{* *} \\
(0.126)\end{array}$ & $\begin{array}{l}0.274^{\star *} \\
(0.109)\end{array}$ & $\begin{array}{l}0.295^{\star \star} \\
(0.120)\end{array}$ & $\begin{array}{l}0.271^{\star *} \\
(0.116)\end{array}$ \\
\hline $41-60 \%$ & $\begin{array}{l}0.175^{\star} \\
(0.094)\end{array}$ & $\begin{array}{l}0.194^{\star} \\
(0.102)\end{array}$ & $\begin{array}{l}0.136 \\
(0.111)\end{array}$ & $\begin{array}{l}0.099 \\
(0.106)\end{array}$ & $\begin{array}{l}0.214^{\star \star} \\
(0.089)\end{array}$ & $\begin{array}{l}0.162^{\star} \\
(0.093)\end{array}$ \\
\hline $61-80 \%$ & $\begin{array}{c}0.077 \\
(0.108)\end{array}$ & $\begin{array}{c}0.006 \\
(0.113)\end{array}$ & $\begin{array}{c}0.164 \\
(0.128)\end{array}$ & $\begin{array}{c}0.073 \\
(0.126)\end{array}$ & $\begin{array}{c}0.110 \\
(0.113)\end{array}$ & $\begin{array}{l}-0.035 \\
(0.119)\end{array}$ \\
\hline$>80 \%$ & $\begin{array}{l}0.269^{\star *} \\
(0.111)\end{array}$ & $\begin{array}{l}0.243^{\star \star} \\
(0.121)\end{array}$ & $\begin{array}{l}0.256^{\star *} \\
(0.127)\end{array}$ & $\begin{array}{c}0.171 \\
(0.118)\end{array}$ & $\begin{array}{l}0.231^{*} \\
(0.120)\end{array}$ & $\begin{array}{l}0.154 \\
(0.127)\end{array}$ \\
\hline L.Foreign ownership (D) & $\begin{array}{l}0.193^{\star} \\
(0.105)\end{array}$ & $\begin{array}{l}0.208^{*} \\
(0.112)\end{array}$ & $\begin{array}{l}0.222^{\star \star} \\
(0.112)\end{array}$ & $\begin{array}{l}0.176^{\star} \\
(0.099)\end{array}$ & $\begin{array}{l}0.227^{\star \star} \\
(0.102)\end{array}$ & $\begin{array}{l}0.214^{* *} \\
(0.102)\end{array}$ \\
\hline L.Works council (D) & $\begin{array}{l}0.206^{\star \star} \\
(0.087)\end{array}$ & $\begin{array}{l}0.196^{\star \star} \\
(0.094)\end{array}$ & $\begin{array}{c}0.102 \\
(0.109)\end{array}$ & $\begin{array}{l}0.183^{\star \star} \\
(0.087)\end{array}$ & $\begin{array}{l}0.190^{\star \star} \\
(0.077)\end{array}$ & $\begin{array}{l}0.170^{* \star} \\
(0.083)\end{array}$ \\
\hline L.Engagement abroad (D) & $\begin{array}{l}0.043 \\
(0.079)\end{array}$ & $\begin{array}{c}0.032 \\
(0.085)\end{array}$ & $\begin{array}{c}0.047 \\
(0.093)\end{array}$ & $\begin{array}{l}-0.027 \\
(0.085)\end{array}$ & $\begin{array}{c}0.008 \\
(0.085)\end{array}$ & $\begin{array}{l}-0.072 \\
(0.088)\end{array}$ \\
\hline L.Exports (D) & $\begin{array}{l}0.235^{\star \star} \\
(0.095)\end{array}$ & $\begin{array}{l}0.186^{*} \\
(0.104)\end{array}$ & $\begin{array}{l}0.353^{\star * *} \\
(0.104)\end{array}$ & $\begin{array}{c}0.343^{\star * *} \\
(0.106)\end{array}$ & $\begin{array}{l}0.342^{\star \star *} \\
(0.102)\end{array}$ & $\begin{array}{l}0.357^{\star \star \star} \\
(0.111)\end{array}$ \\
\hline Observations & 344 & 300 & 325 & 284 & 328 & 284 \\
\hline R-squared & 0.242 & 0.234 & 0.266 & 0.339 & 0.330 & 0.341 \\
\hline Adjusted R-squared & 0.187 & 0.171 & 0.210 & 0.280 & 0.279 & 0.283 \\
\hline
\end{tabular}

Notes: OLS estimations with lagged independent variable. Dependent variables are calculated per employee. All independent variables refer to 2008. Operating Revenue, Sales and Labor are taken from BVD. Robust standard errors are in parentheses. Industry dummies, settlement dummies and noise control included. Noise controls include gender, tenure and position of respondent as well as a dummy for answering online. $\mathrm{D}$ indicates a dummy variable. Asterisks indicate significance levels: ${ }^{*} p<0.10$, ** $p<0.05,{ }^{* * *} p<0.01$. Sample standard deviations are provided upon request.

Source: Own calculations based on GMOP linked with BvD. 